\title{
The Gyra washover fan in the Lefkada Lagoon, NW Greece-possible evidence of the 365 AD Crete earthquake and tsunami
}

\author{
Simon Matthias May ${ }^{1}$, Andreas Vött ${ }^{2}$, Helmut Brückner ${ }^{1}$, and Alessandra Smedile ${ }^{3}$ \\ ${ }^{1}$ Institute for Geography, Universität zu Köln, Albertus-Magnus-Platz, D-50923 Köln (Cologne), Germany \\ ${ }^{2}$ Institute for Geography, Johannes Gutenberg-Universität Mainz, Johann-Joachim-Becher-Weg 21, D-55099 Mainz, Germany \\ ${ }^{3}$ Istituto Nazionale di Geofisica e Vulcanologia, Via di Vigna Murata 605, 00143 Rome, Italy
}

(Received October 31, 2010; Revised November 11, 2011; Accepted March 31, 2012; Online published October 24, 2012)

\begin{abstract}
Coastal geomorphological and geological archives store valuable information about the geodynamic evolution of coastal areas and the contributing geomorphodynamic processes. The coastal geomorphology of the LefkadaPreveza coastal zone, NW Greece, holds evidence for the influence of both gradual, low-energy and episodic, high-energy coastal processes. Situated close to the Hellenic Arc and the Cefalonia transform fault, the area belongs to one of the seismically most active regions in the Mediterranean. Thus, tsunami events are assumed to have contributed to the coastal evolution in the study area according to tsunami catalogues and field evidence from previous investigations. The northern part of the Lefkada Lagoon, separated from the Ionian Sea by an extensive barrier beach system, is characterized by a number of fan-like washover structures, formed by different washover generations. In this paper, we present detailed geomorphological, sedimentological, geochemical and foraminiferal investigations on the most prominent fan structure, the Gyra fan, based on terrestrial and lagoonal sediment cores. The Gyra fan consists of a coarse-grained sequence of fully marine origin on top of lagoonal mud and a palaeosol, respectively. The sequence shows numerous characteristics of extreme wave deposits. Due to the dimension and morphology of the fan, the existence of up to four consistent and correlative stratigraphic subunits, their landward thinning and their comparable sedimentary characteristics, we argue that a tsunami event induced the formation of the Gyra fan, comprising at least four major inundation impulses. According to radiocarbon dates, this geomorphological structure was most likely formed by teletsunami effects triggered by the 365 AD earthquake off western Crete.
\end{abstract}

Key words: Eastern Mediterranean, Lefkada Lagoon, washover fan, tsunami deposits, foraminifera, 365 AD tsunami.

\section{Introduction}

Fan-shaped sedimentary structures extending from barrier beach systems into backbeach coastal lagoons or coastal lowlands are described worldwide and represent an important feature of coastal geomorphology. In most cases, they are interpreted as (i) washover fans, resulting from the flow of water and sediment (overwash) over the crest of the beach, or (ii) scour fans, formed during breaching of the barrier beach (Andrade, 1992; Andrade et al., 2004; Donnelly et al., 2004; Matias et al., 2008). They are generally induced by high-energy extreme wave events such as tsunamis, tropical cyclones, or extra-tropical winter storm surges (e.g. Dawson, 1996; Luque et al., 2002; Sedgwick and Davis, 2003; Matias et al., 2008; Morales et al., 2008; Switzer and Jones, 2008a; Goff et al., 2009). During the recent past, the number of studies which deal with sedimentary characteristics of washover sediments and/or structures and focus on an event-induced origin has increased (e.g. Tuttle et al., 2004; Morton et al., 2007; Switzer and Jones, 2008b; Williams, 2009; Engel et al., 2010). However, in

Copyright (c) The Society of Geomagnetism and Earth, Planetary and Space Sciences (SGEPSS); The Seismological Society of Japan; The Volcanological Society of Japan; The Geodetic Society of Japan; The Japanese Society for Planetary Sciences; TERRAPUB.

doi:10.5047/eps.2012.03.007 many cases, problems with the unambiguous determination of their origin remain, in particular when only the sedimentary record or the geomorphological structure, but no historical reports of the event itself are available. The distinguishability of tsunami and storm in the geological record is therefore a challenge of major importance in sedimentary research and in the research on extreme wave events in general (e.g. Goff et al., 2004; Kortekaas and Dawson, 2007; Morton et al., 2007; Switzer and Jones, 2008a; Mamo et al., 2009; Benner et al., 2010). Against this background, detailed sedimentary analyses and descriptions of palaeowashover structures and their sedimentary composition as well as comparisons with recently formed storm washovers are required.

In this paper, investigations on the Gyra fan, a large fan structure in the northern Lagoon of Lefkada, are presented. By means of a broad range of methods, this study aims (i) to provide a detailed documentation of the Gyra fan's geomorphological structure and sedimentary architecture; (ii) to verify the event-induced origin of the fan structure; (iii) to attempt a comprehensible determination of the related hydrodynamic process (tsunami or storm) which induced the washover structure; (iv) to date the triggering event; and thereby (v) to verify earlier investigations of Vött et al. (2006, 2009a), who suggested a tsunamigenic origin of 


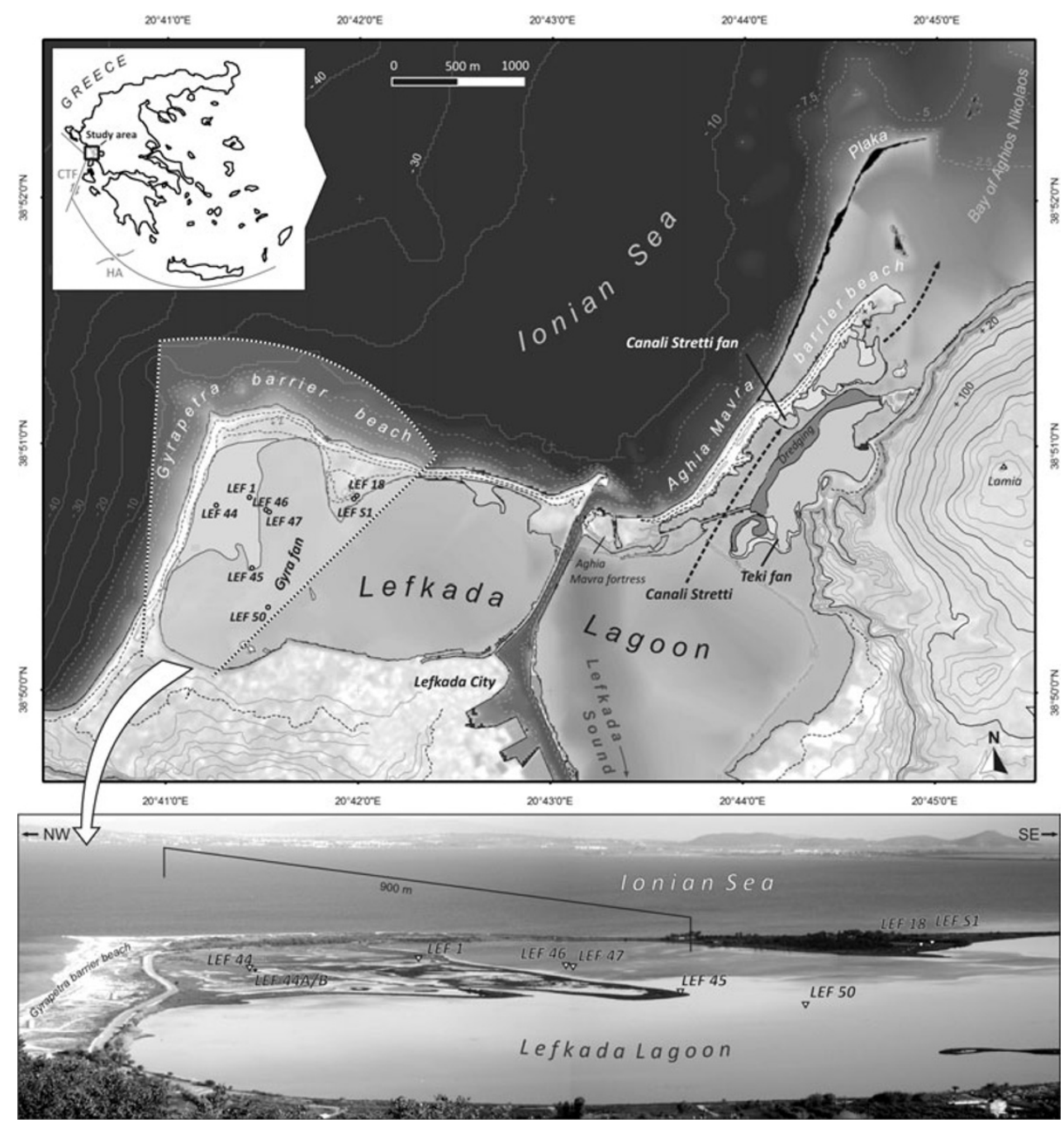

Fig. 1. (top): Overview of the study area, comprising the northern part of the Lefkada Lagoon and the Lefkada barrier beach system [map based on Aster Satellite Image 2003 (USGS, 2006), Topographic Map 1:50.000 sheets Lefkada and Vonitsa (Hellenic Military Geographical Service, HMGS, 1987), Bathymetrical charts Amvrakikos Gulf and Lefkada channel (Hellenic Navy Hydrographic Service, HNHS) and SRTM elevation data (NASA, 2006)]. (bottom): The Gyra washover fan. On top of its surface, three sediment cores were taken for stratigraphical interpretation (LEF 1, LEF 44, LEF 45). Sediment cores LEF 46, LEF 47 and LEF 50 were conducted in the Lagoon of Lefkada, vibracore LEF 18 and sediment profile LEF S1 on top of a triangle-shaped peninsula.

the Gyra fan and further neighbouring fan structures.

\section{Study Area}

\subsection{Physical setting}

The area between Lefkada Island and the Bay of Aghios Nikolaos (NW Greece) is characterized by a barrier beach system, separating the shallow Lagoon of Lefkada from the open Ionian Sea (Fig. 1). The base of this barrier system is made up of beachrock down to approximately $12 \mathrm{~m}$ below present mean sea level (b.s.1.). Both the present barrier and the adjacent beachrock mainly consist of coarse sand and well rounded gravel. Towards the north, the recent beach ridge is shifted eastwards and separated from its beachrock base, the so-called Plaka, which is partly submerged, fragmented and, due to the effects of earthquakes, partly broken (as suggested by Vött et al., 2006, 2007). Here, the remains of the Plaka represent a reef-like palaeo-coastline, protecting the Bay of Aghios Nikolaos from the open sea.

The northern part of the Lefkada Lagoon is characterized by several fan-shaped washover structures, reaching from the recent barrier beach into the Lagoon. The Gyra fan is situated in the western part of the Lefkada Lagoon and represents, with $390,000 \mathrm{~m}^{2}$ (area above mean sea level, a.s.1.), the most extensive fan structure in the study area (Fig. 1). In the eastern part of the Lefkada Lagoon, distinct lobe-like fan structures reach southwards into the lagoon (Teki fan structure, Fig. 1). The related marshy plain is separated from the recent beach system by the so-called Canali Stretti, a former channel leading from the central part of the Lagoon of Lefkada in north-eastern direction into the Bay of Aghios Nikolaos. It was used to navigate across the Lefkada Sound from Antiquity until the beginning of the 19th century (e.g. Partsch, 1907). Several smaller fan structures extend from the recent barrier beach into the area of the former Canali Stretti in south-eastern direction (e.g. Canali Stretti fan, Fig. 1). Investigations on the washover structures in the eastern part of the Lefkada Lagoon were carried out by Vött et al. (2008, 2009a), May (2010) and May et al. (2012) (see also Fig. 2).

The study area is exposed to the northern part of the 


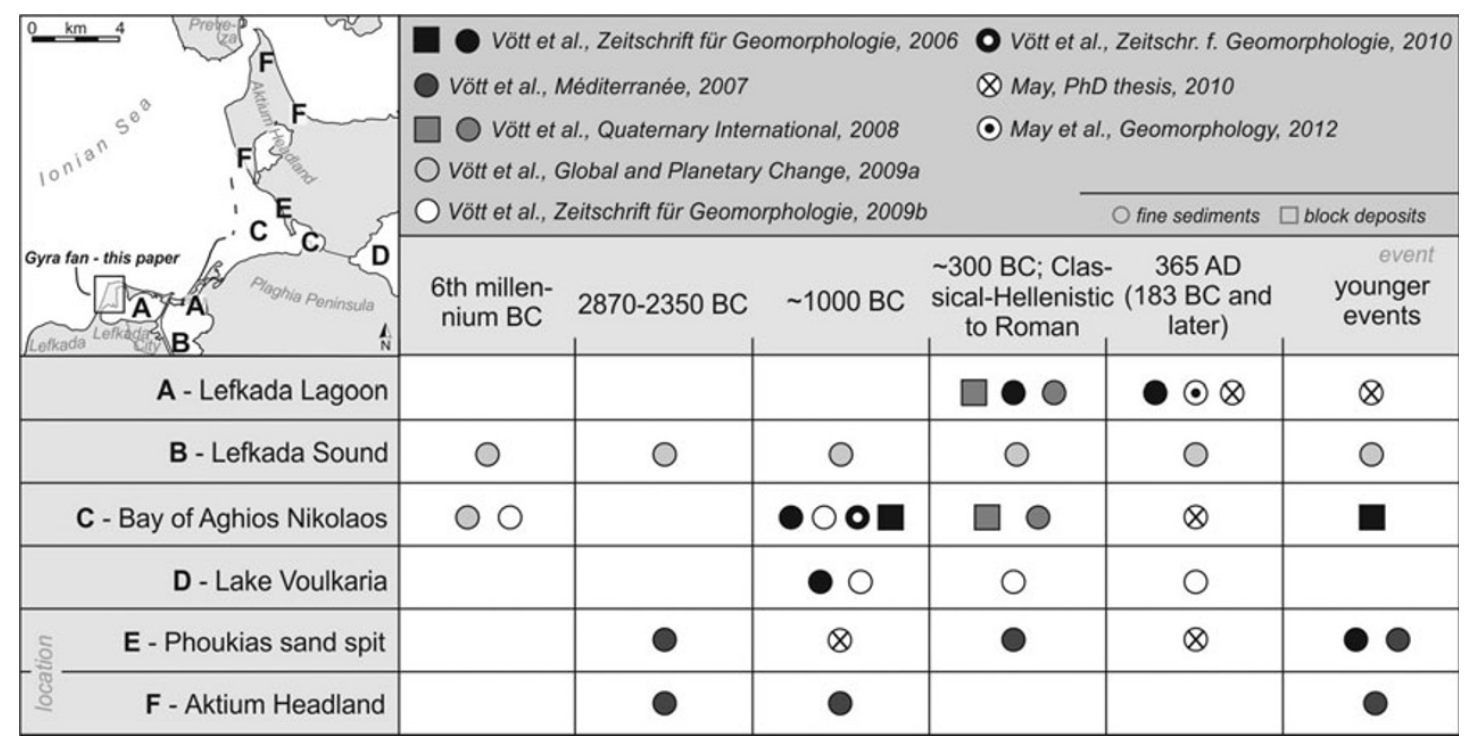

Fig. 2. Compilation of previous publications about extreme wave events in the study area. Most of the event deposits were interpreted to be of tsunamigenic origin. The main conclusions (dating of events, location, type of deposit) are depicted (modified from May et al., 2012).

subduction zone of the Hellenic Arc (HA, Fig. 1). To the north of the Hellenic Arc, the Cefalonia transform fault (CTF) shows a remarkably high seismic activity (Louvari et al., 1999; Sachpazi et al., 2000; Papadopoulos et al., 2003). Therefore, the study area belongs to the seismically most active regions of the Mediterranean and owns a high tsunamigenic potential (Papazachos and Dimitriu, 1991).

Vött (2007) detected differences in the local relative sea-level history of several study areas along the adjacent coastal Akarnania (NW Greece), caused by the tectonic setting and the related crustal movements of the Akarnanian block (e.g., Haslinger et al., 1999; Doutsos and Kokkalas, 2001). During the Holocene, no higher sea level than the present one is inferred for the entire area. A moderate relative sea-level rise of c. $3.5 \mathrm{~m}$ was documented for the adjacent Palairos coastal plain throughout the last 6000 years, increasing during the last 2000 years (Vött, 2007).

In the Mediterranean, storm intensity is lower compared to other coastlines around the world, but severe storms occur in the Ionian Sea as well. In general, these storms originate from large extra-tropical Mediterranean or Atlantic winter cyclones, but tropical-like cyclone storm systems crossing the Ionian Sea are reported (e.g., Emanuel, 2005; Barbano et al., 2010). Significant wave heights during storm events in the open Ionian Sea reach 4-7 m on average (http://www.idromare.com; http://www.poseidon.hcmr.gr; see also Scicchitano et al., 2007; Vött et al., 2009a; Barbano et al., 2010). Though generally remaining below c. $30 \mathrm{~cm}$, Krestenitis et al. (2011) infer a maximum storm surgeinduced sea-level rise of c. $44 \mathrm{~cm}$ at Lefkada for the 5-year period between 2000 and 2004. No information is available about near-shore wave heights.

The effects of a severe storm (duration $14 \mathrm{~h}$; Nov. 10, 2007 ) with winds $>44$ knots (equivalent to $\sim 9$ on the Beaufort scale) on the Lefkada barrier system, inducing a temporary sea-level rise of up to $19 \mathrm{~cm}$, was documented by Ghionis et al. (2008). In the open Ionian Sea, wave heights of $>5 \mathrm{~m}$ can be assumed during this event. The related near- shore waves impacting the Lefkada barrier are reported to have exceeded inundation distances of $50 \mathrm{~m}$, overtopping the barrier at some places but scarcely reaching the lagoon; geomorphological changes of the back-beach area are not reported. It is concluded that, beside changes of the beach geomorphology, considerable amounts of sediment were removed from the system (Ghionis et al., 2008).

According to May (2010), the washover structures in the Lefkada area have not been affected by modifications at least during the last 150 years, leading to the assumption that normal storm activity of annual, decadal or even centennial intensity does not significantly influence the backbeach area, and is not capable of generating extensive fanshaped washover and/or breaching structures in the Lefkada coastal zone. Since the study area belongs to a region of remarkably high seismic activity and tsunami recurrence rates, the occurrence of tsunami of variable magnitudes is very likely (Vött et al., 2006). However, nor younger tsunami events reported by tsunami catalogues for the years $1867,1869,1914,1915$ and 1948 significantly altered the backbeach geomorphology in the study area (May, 2010).

\subsection{Previous findings}

For the Lefkada-Preveza area, repeated impact of tsunami events was suggested during the recent past based on sedimentary and geomorphological investigations on present coastal geoarchives (cf. Vött et al., 2006; Fig. 2). Sand/shell debris layers intercalating the sedimentary sequence of sediment cores from the inner Lefkada Sound area were interpreted as tsunami deposits (Vött et al., 2009a). Washover structures in the eastern Lefkada Lagoon were dated to Classical-Hellenistic times (Vött et al., 2008) but may also be related to the 365 AD event (May, 2010; May et al., 2012). High energy wave impact was also inferred in the Bay of Aghios Nikolaos due to several coarse clastic sediment layers which could be traced even in the western part of the Lake Voulkaria (Vött et al., 2008, 2009b, 2010). Event deposits stored in sedimentary archives along the coasts of Aktium Headland, including the Phoukias sand 
Table $1 .{ }^{14} \mathrm{C}$-AMS dating results used for the geochronological interpretation of the stratigraphy.

\begin{tabular}{lcclcccc}
\hline \multicolumn{1}{c}{ Sample } & $\begin{array}{c}\text { Depth } \\
(\mathrm{m} \text { b.s.1. })\end{array}$ & Lab. No. & Sample description & $\begin{array}{c}\delta^{13} \mathrm{C} \\
(\mathrm{ppm})\end{array}$ & $\begin{array}{c}{ }^{14} \mathrm{C} \text { age } \\
(\mathrm{BP})\end{array}$ & $\begin{array}{c}1 \sigma \text { max-min } \\
(\mathrm{cal} \mathrm{BC} / \mathrm{AD})\end{array}$ & $\begin{array}{c}2 \sigma \text { max-min } \\
(\mathrm{cal} \mathrm{BC} / \mathrm{AD})\end{array}$ \\
\hline LEF 1/4+ PR & 1.21 & KIA28881 & sea weed & -15.9 & $1965 \pm 25$ & $* 387-472 \mathrm{AD}$ & $* 349-533 \mathrm{AD}$ \\
LEF 44/10+ PR & 0.98 & UCI73834 & unid. plant remains & - & $2375 \pm 15$ & $\# 481-397 \mathrm{BC}$ & $\# 509-395 \mathrm{BC}$ \\
LEF 45/9 PR & 0.64 & UCI73835 & unid. plant remains & -9.9 & $2085 \pm 15$ & $\# 155-55 \mathrm{BC}$ & $\# 165-51 \mathrm{BC}$ \\
LEF S1/3 M & -0.29 & KIA39788 & single C.g. valve & -7.93 & $2635 \pm 30$ & $* 399-339 \mathrm{BC}$ & $* 475-258 \mathrm{BC}$ \\
\hline
\end{tabular}

Notes: unid. plant remains_-unidentified plant remains. C.g.-Cerastoderma glaucum. Lab. No.-laboratory number, University of Kiel (KIA), University of California, Irvine (UCI). *-marine reservoir correction with 400 years of reservoir age. “\#”-calibration yielded several possible age intervals because of multiple intersections with the calibration curve; the oldest and youngest possible ages are depicted.

spit, were interpreted to be of tsunamigenic origin (Vött et al., 2007; May, 2010). Finally, May et al. (2012) concluded that extreme wave events significantly influenced the coastal evolution in the Lefkada-Preveza area. A compilation of the previous findings is presented in Fig. 2.

\section{Methods}

Field work comprised three vibracorings performed by means of an Atlas Copco Cobra mk 1 coring device and sediment cores of $5 \mathrm{~cm}$ and $6 \mathrm{~cm}$ in diameter. Additionally, on top of the washover structure and in the adjacent lagoonal area, four sediment cores were obtained by pushing plastic tubes, $2 \mathrm{~m}$ long and $5 \mathrm{~cm}$ in diameter, into the sediment by hand. DGPS measurements were carried out to determine the exact elevation and position of the cores using a Leica SR 530 differential GPS. Supplementary field work comprised terrestrial geomorphological mapping as well as the examination of sediment profiles in trenches.

Vibracore and sediment profiles were documented and sampled in the field according to Ad-hoc Arbeitsgruppe Boden (2005). Sedimentological, geochemical and macroand microfaunal analyses were realized in the laboratory. The air-dried and hand-pestled fine grained fraction $(<2$ $\mathrm{mm}$ ) of samples (LEF 1 and 18) was analysed for $\mathrm{Ca}, \mathrm{Fe}$, $\mathrm{Na}$, and $\mathrm{K}$ concentrations using atomic absorption spectrometry (AAS, Perkin Elmer A-Analyst 300). $\mathrm{CaCO}_{3}$ was measured following the Scheibler method (Beck et al., 1995). Loss on ignition (LOI) was determined using a muffle furnace after the procedure described by Beck et al. (1995). Inorganic element composition was measured for selected core profiles (LEF 44, 45, 47 and 50) using a NITON XL3t 900 GOLDD X-ray fluorescence (XRF) hand-held elemental analyzer (Thermo Scientific). Total amounts of around 30 elements were measured. XRF analyses by means of modern portable systems produce high accuracy analytical results. The results are consistent with standard or specific calibrations, with results from traditional laboratory XRF systems and with elemental concentrations measured in acidic solutions, as documented by numerous comparative studies on sediments, soils, and other materials (e.g., Radu and Diamond, 2009; Zhu and Weindorf, 2009; Kenna et al., 2010; Vött et al., 2011). Scanning resolution was between $1 \mathrm{~mm}$ and several centimetres, exposure time was $30 \mathrm{sec}$. For selected cores, grain size analyses were carried out. Samples were airdried and dry-sieved in $\varphi$-intervals through sieves between $4 \varphi$ and $-5 \varphi(0.063 \mathrm{~mm}-32 \mathrm{~mm})$ following the nomencla- ture of Blott and Pye (2001). Large organic remains were removed before analyses. Microfaunal studies were carried out for samples from core LEF 44 in order to support textural and geochemical results and to determine sediment source areas. Samples $\left(10 \mathrm{~cm}^{3}\right)$ were pre-treated with $\mathrm{H}_{2} \mathrm{O}_{2}$ (30\%) for dispersion, and wet-sieved through sieves of 63 $\mu \mathrm{m}$ and $125 \mu \mathrm{m}$. The foraminiferal content was investigated under a binocular microscope and recorded semiquantitatively. At least 100 benthic forms were counted from each sample where sufficient numbers of individuals were available. Any planktonic foraminifera encountered were additionally picked. Selected species were photographed using a JEOL JSM-6500F thermal field emission scanning microscope (FESEM). Identification of species was supported by original description and several key papers (AGIP, 1982; Cimerman and Langer, 1991). Palaeoenvironmental interpretation of assemblages was inferred by references describing modern assemblages (e.g. Sgarrella and Moncharmont Zei, 1993; Murray, 2006).

For the chronological framework, organic material and mollusc remains taken from the sediment cores were dated by ${ }^{14} \mathrm{C}$-AMS (Table 1 ). ${ }^{14} \mathrm{C}$-AMS ages were corrected for a marine reservoir effect of 400 years if necessary (Reimer and McCormac, 2002) using CALIB 6.0 software and the dataset of Reimer et al. (2009). For plant remains identified as sea weed (Posidonia sp.) in the field marine calibration was carried out when $\delta^{13} \mathrm{C}$-values were $15 \%$ $\pm 3 \%$ (Walker, 2005).

\section{Results}

\subsection{Stratigraphy of the Gyra washover structure}

4.1.1 Description of coring transect A Coring transect A comprises, from north-west to south-east, vibracore LEF 44, core LEF 45 and lagoonal core LEF 50 (Figs. 1, $3,7)$. At all coring sites of transect A, the sedimentary sequence starts with grey, homogeneous, clayey to silty deposits, containing in-situ mollusc remains (Fig. 3, see also Section 4.2). In all other sediment cores from the Gyra fan structure and the adjacent lagoonal area (in transects A and B), these muddy sediments were encountered in a similar stratigraphical position. Above, a coarse-grained sedimentary sequence was detected which can be subdivided into several subunits, showing comparable sedimentary and geochemical characteristics (Figs. 3, 4). Compared to core LEF 44 , this coarse-grained sequence is considerably thinner at coring sites LEF 45 and 50, the latter situated some $200 \mathrm{~m}$ to the south in the Lefkada Lagoon (Figs. 3, 7). 

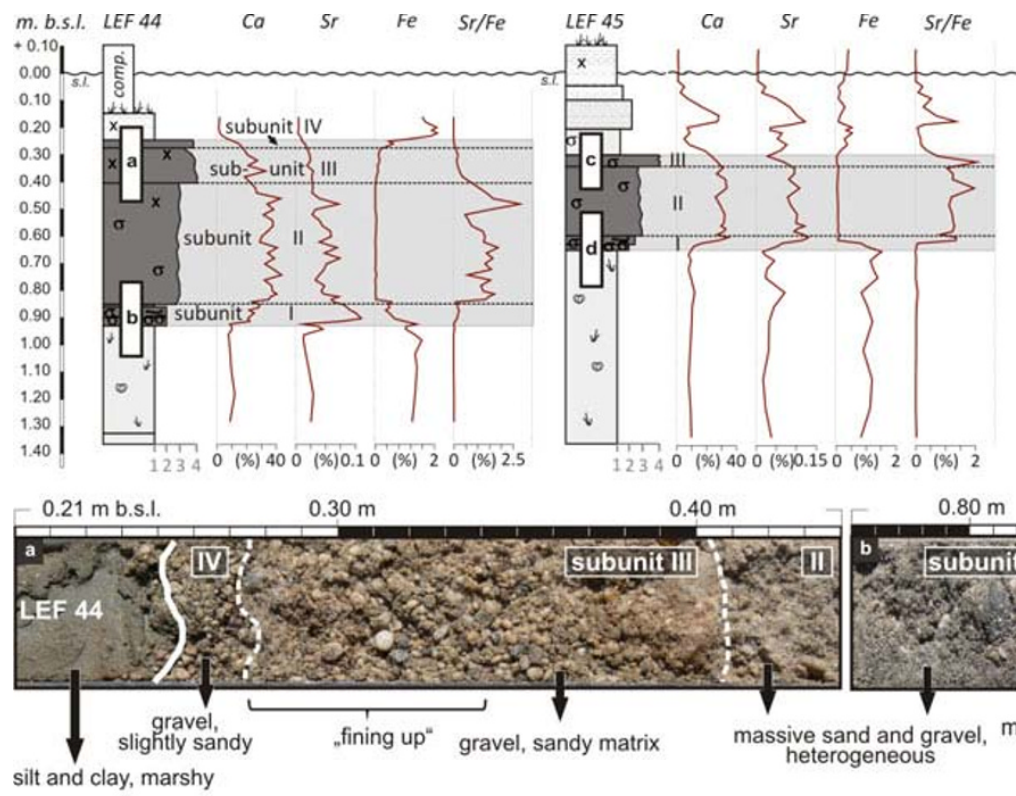

$0.40 \mathrm{~m}$
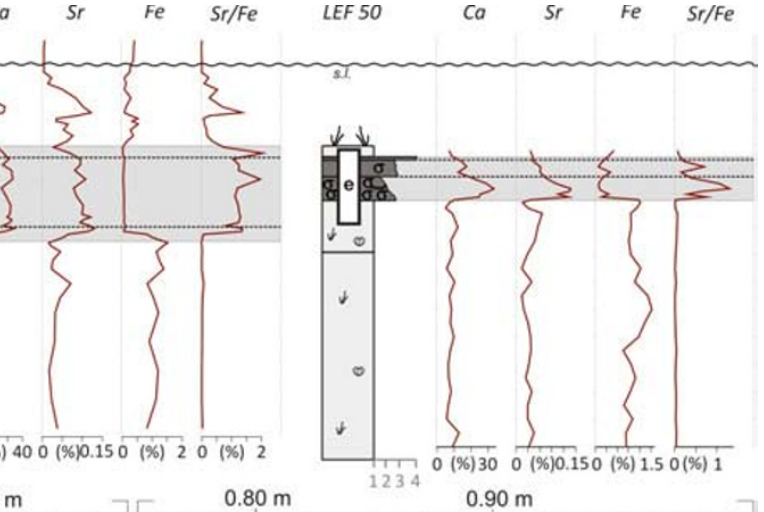

$1234 \quad 0.90 \mathrm{~m}$

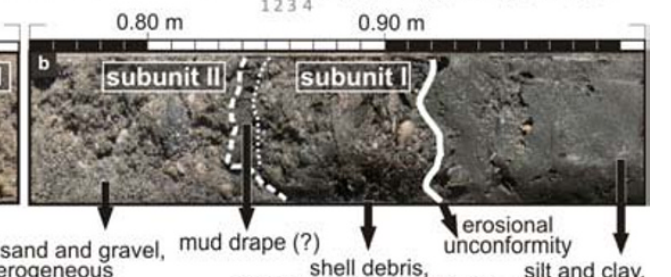

massive sand and grave
heterogeneous

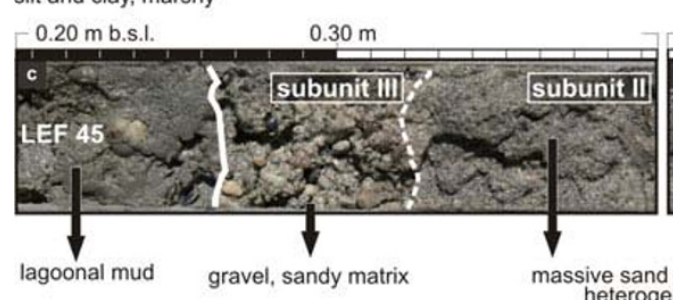

$7-0.50 \mathrm{~m}$ shell debris,
abundant organic remains
lagoonal muc
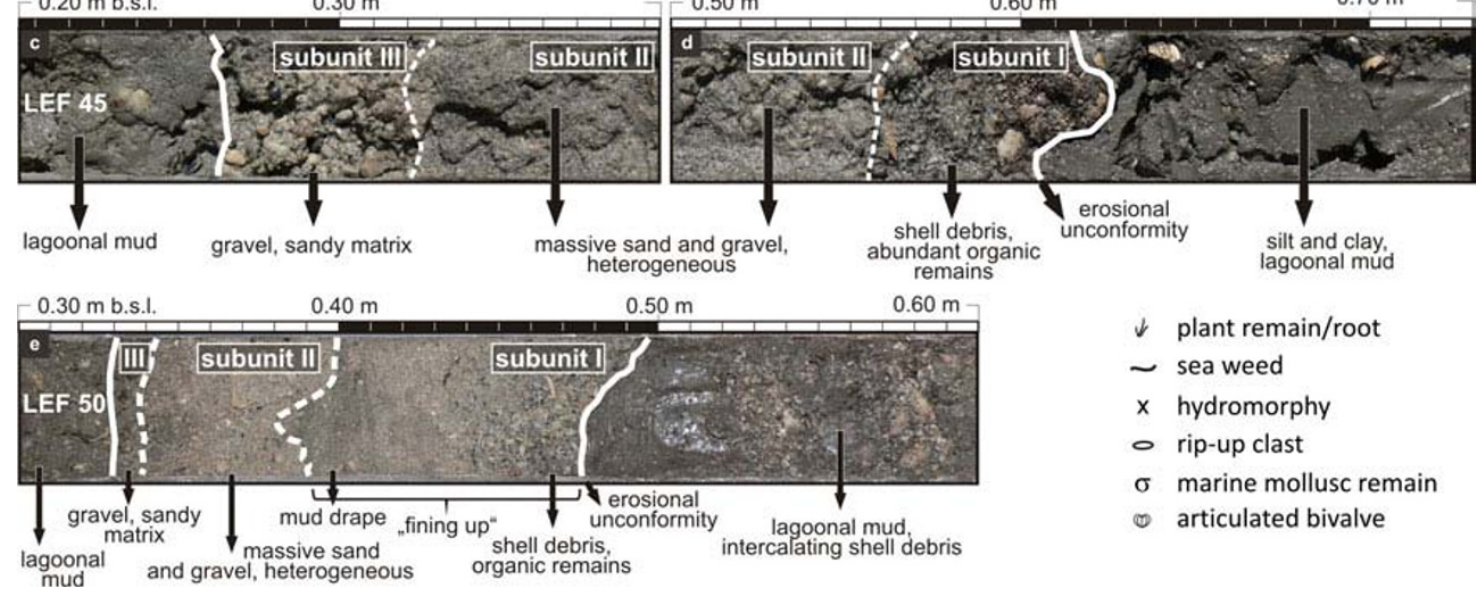
silt and clay,
lagoonal mud

$\downarrow$ plant remain/root

$\sim$ sea weed

$x$ hydromorphy

- rip-up clast

$\sigma$ marine mollusc remain

( ) articulated bivalve

Fig. 3. (top): Schematic view of sediment cores LEF 44, LEF 45 and LEF 50 with selected geochemical proxies Ca, Sr, Fe, and Sr/Fe ratio from XRF measurements. Different sedimentary units are distinguishable by a distinct distribution of elements. The marked washover unit is characterized by high $\mathrm{Sr}$ and $\mathrm{Ca}$ values. For the lower part of the washover sequence, a mixing of deposits from different depositional environments is documented. Relative width of core sections represents grain size composition (1-mainly silt and clay, 2-sand, 3-sand and gravel, 4-mainly gravel). For legend see also Fig. 7. (bottom): Different core sections of cores LEF 44, LEF 45 and LEF 50. Main sedimentary characteristics are depicted. On top of the lagoonal mud, a coarse-grained sequence was found, comprising up to four different subunits (I, II, III, IV). Mud drapes were found in cores LEF 44 and LEF 50. In core LEF 50, subunit I shows a clear fining-up sequence. Subunits II and III are clearly thinning landward.

Subunit I can be described as a bioclastic layer consisting of shell debris (Fig. 3, e.g. LEF 44: 0.92-0.85 m b.s.l.; LEF 45: $0.61-0.56 \mathrm{~m}$ b.s.1.), characterized by a heterogeneous grain size distribution (Fig. 5) and an erosional unconformity at its base. In LEF 44, coarser grain sizes ( $>4 \mathrm{~mm}$ ) show slightly higher values in its lower part (sample LEF 44/10) and point to a fining-upward trend. Here, the top of the bioclastic unit, at the transition to the overlying subunit II, is marked by a thin mud layer (Fig. 3, 0.85-0.84 m b.s.1.). At coring site LEF 50, subunit I (Fig. 3, 0.50-0.40 m b.s.1.) is characterized by a clear fining and sorting-upward trend (Fig. 5, samples LEF 50/6, 50/5 and 50/4), passing into a sandy mud layer towards the top. Here, subunit I is thicker $(\sim 10 \mathrm{~cm})$ compared to cores LEF 44 and LEF 45.

Above, a sharp, erosive contact to the subsequent massive, heterogeneous subunit of sand and gravel is documented (subunit II, Fig. 3, LEF 44: 0.84 and $0.40 \mathrm{~m}$ b.s.1., LEF 45: 0.56-0.32 m b.s.1., LEF 50: 0.40-0.34 m b.s.1.). For the cores of transect $\mathrm{A}$, in contrast to transect $\mathrm{B}$, the grain size distribution of subunit II indicates an overall bimodal pattern for the investigated samples, characterized by two peaks at $>0.125-0.250 \mathrm{~mm}$ and, less pronounced, at $>2$ $\mathrm{mm}$ (Fig. 5). Sections of higher and lower gravel content are present in particular at coring site LEF 44, but no clear internal sublayering could be inferred from the core. Thus, within this subunit, the amount of coarser grain sizes $(>4$ $\mathrm{mm}$ and $>8 \mathrm{~mm}$ ) is slightly different for the investigated samples (Fig. 5). However, for coring sites LEF 44, 45 and 50 , an overall fining-upward trend can be observed. At coring sites LEF 45 and 50, the grain size peaks appear less defined and show a broader grain size spectrum. Here, no bimodal pattern can be observed in the upper part of the subunit, and grain size fractions peak between $>0.250$ and $>0.125 \mathrm{~mm}$ (e.g. LEF 45/5, 50/1).

The following subunit III is constituted by a distinct layer of gravel within a sandy matrix (Fig. 3, LEF 44 and 45). 


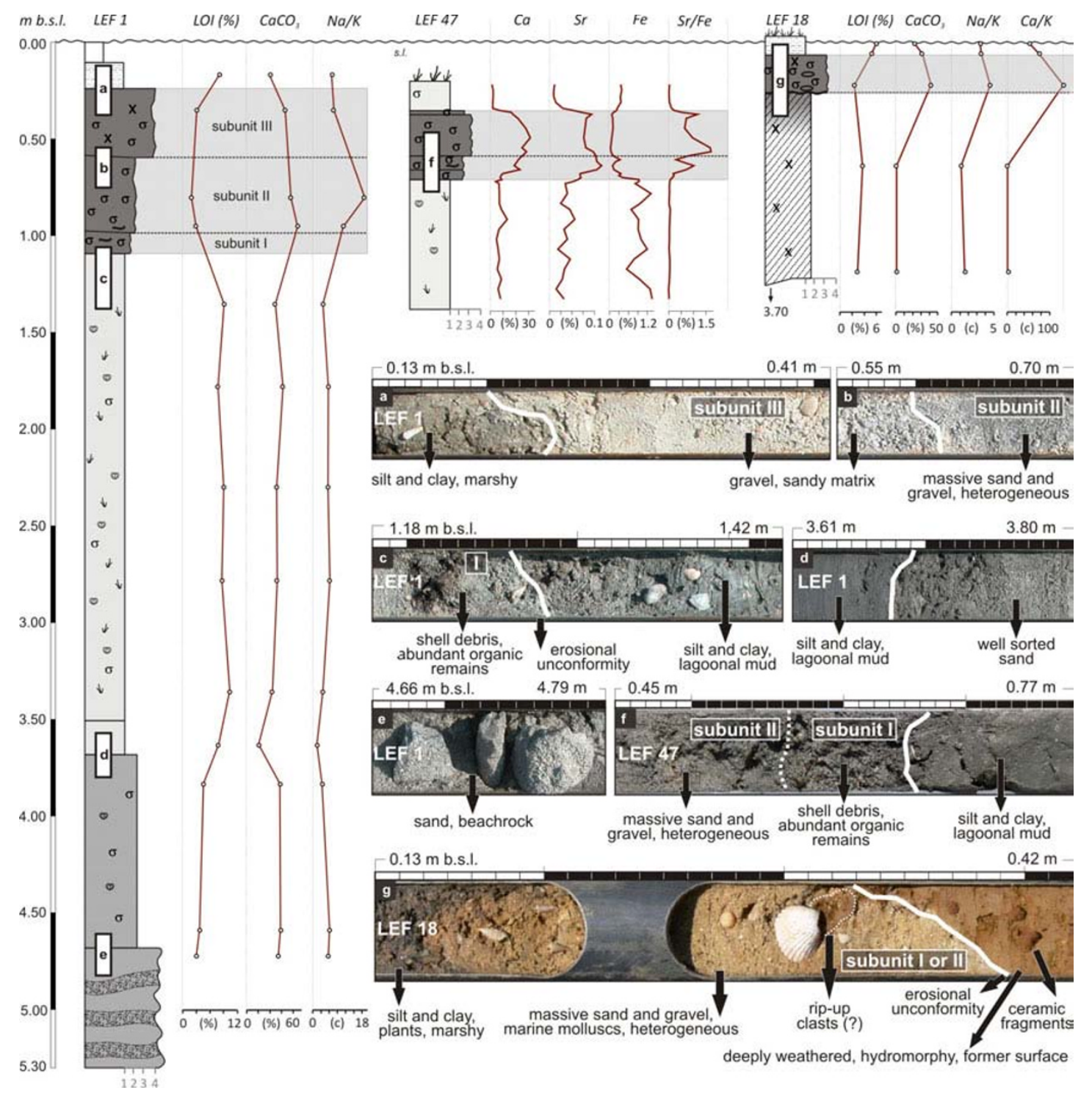

Fig. 4. (top): Schematic view of sediment cores LEF 1, LEF 18 (AAS) and LEF 47 (XRF) with selected geochemical proxies. Findings for core LEF 46 are analogous to core LEF 47, for trench LEF S1 analogous to the upper part of core LEF 18. Different sedimentary units are characterized by a distinct distribution of elements. Relative width of core sections represents grain size composition (1-mainly silt and clay, 2-sand, 3-sand and gravel, 4-mainly gravel). For legend see also Figs. 3 and 7. (bottom): Different core sections of cores LEF 1, LEF 47 and LEF 18. Main sedimentary characteristics are depicted. On top of the lagoonal mud and a former surface, a coarse-grained sequence was found which is thinning landward. In core LEF 18, only one subunit (I or II) was found.

It is well separated from the underlying subunit II by an erosional unconformity and a distinct shift in grain size. Again, a bimodal grain size distribution is indicated by a well-developed peak at $>2 \mathrm{~mm}$ and $<0.250 \mathrm{~mm}$ (Fig. 5). Similar to the underlying subunit II, gravel pieces are characterized by perfect rounding, but show smaller sizes. For LEF 44, a fining upward trend is documented by increasing sand contents at the top (Fig. 5, samples LEF 44/3, 44/2, 44/1). At coring site LEF 50, subunit III is represented by a thin gravel-containing layer, $\sim 1 \mathrm{~cm}$ thick (Fig. 3 ).

An additional subunit IV was exclusively detected in core LEF 44 (Figs. 3, 5, sample LEF 44/1a). It consists of a thin layer of very well rounded fine gravel in a slightly sandy matrix. To the top, at the transition to the overlying sediment, silt and clay content increases.

In all cores from the Gyra fan and the adjacent lagoon, the coarse-grained sequence is covered by greyish or brownish, homogeneous sediments, mainly consisting of clay and silt. These fine-grained sediments accumulated due to the (sub-) recent quiescent depositional environment, which is, compared to the basal unit of homogenous mud, characterized by an analogous geochemical pattern (Figs. 3, 4). At some places, minor parts of (possibly reworked) fine sand were encountered.

4.1.2 Description of coring transect $B$ Coring transect B comprises, from west to east, vibracores LEF 44 (see Section 4.1.1) and LEF 1 (cf. Vött et al., 2006), lagoonal cores LEF 46 and LEF 47 as well as vibracore LEF 18 and sediment profile LEF $\mathrm{S} 1$, the latter representing a trench dig up some $800 \mathrm{~m}$ east of coring site LEF 1 on top of a triangle-shaped peninsula (Figs. 1, 4, 7).

At the base of the deepest core (LEF 1), homogeneous, well sorted medium to fine sand was encountered (Fig. 4), characterized by a unimodal grain size distribution (Fig. 5) 

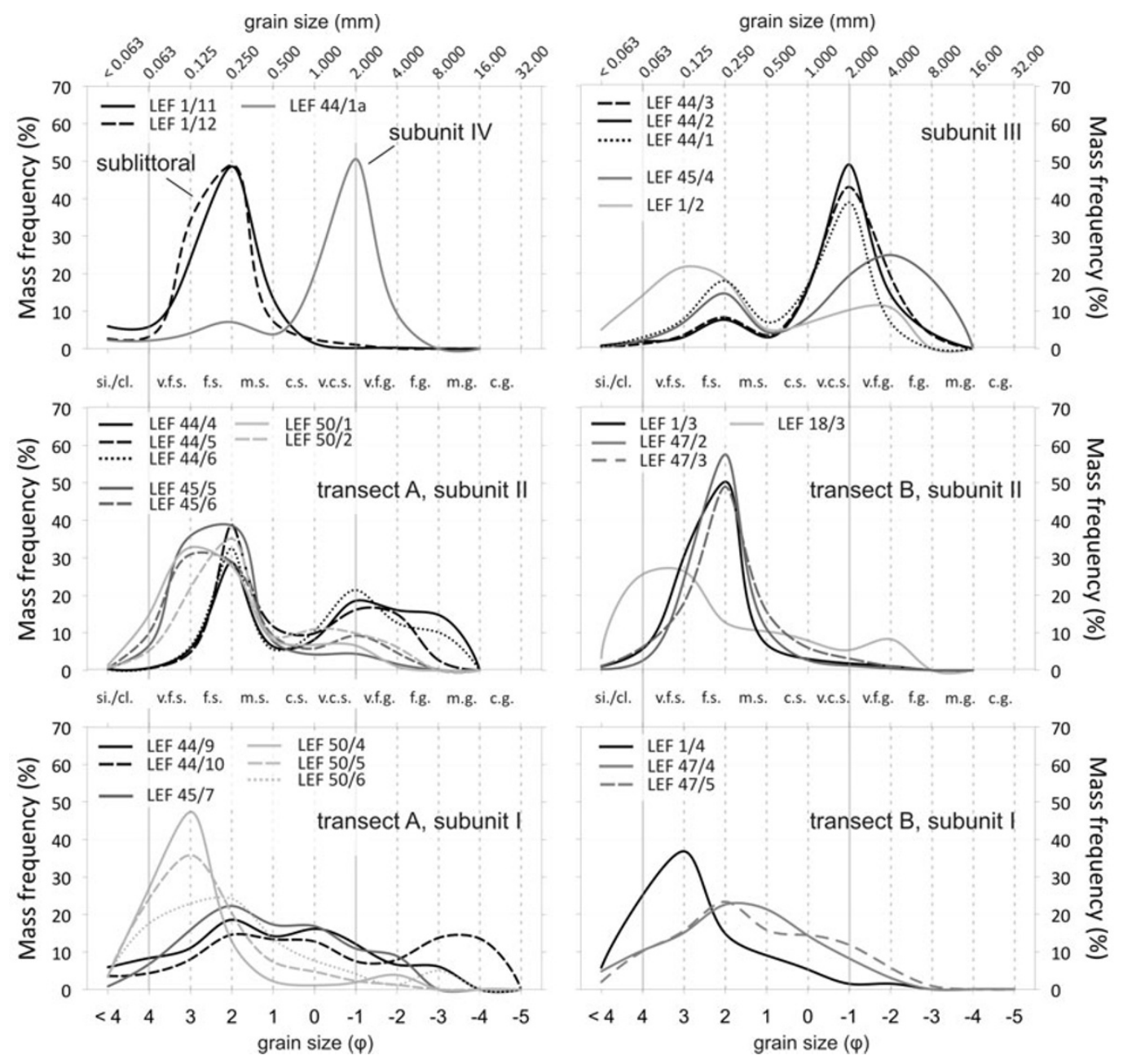

Fig. 5. Results of grain size analyses carried out for selected samples of cores LEF 1, LEF 18, LEF 44, LEF 45, LEF 47 and LEF 50 . Units of $x$-axis represent distances in $\varphi$ (bottom) and distances in $\mathrm{mm}$ (top) of used sieves. Nomenclature of grain size fractions after Blott and Pye (2001): si./cl.—silt and clay, v.f.s. — very fine sand, f.s.—-fine sand, m.s. — medium sand, c.s. — coarse sand, v.c.s.—very coarse sand, v.f.g.—very fine gravel, f.g.- fine gravel, m.g.-medium gravel, c.g.—coarse gravel.

and containing few mollusc and sea weed remains. In its lower part, the sand is cemented to beachrock or beachrocklike material. This basal unit is covered by grey, homogeneous, clayey to silty deposits, containing in-situ mollusc remains and characterized by a different geochemistry (Figs. 3, 4, see also Section 4.2). These muddy sediments were encountered at the base of all other sediment cores from the Gyra fan.

Similar to transect A, the thick unit of homogeneous mud is followed by a coarse-grained sequence at coring sites LEF 1, 46 and 47, for which entirely different geochemical characteristics are documented compared to the above and below lying sediments (Figs. 3, 4, see also Section 4.2). This coarse-grained sequence can be subdivided into three subunits (I, II and III) at coring site LEF 1.

Comparable to transect A, subunit I can be described as a bioclastic layer consisting of shell debris (Fig. 4, LEF 1 and LEF 47). An erosional unconformity separates the shell debris layer from the underlying homogeneous mud. It is characterized by a heterogeneous grain size distribution (Fig. 5), although differing between cores LEF 1 (LEF 1/4) and 47 (LEF 47/4 and 5).

Subsequent subunit II is well separated from the under- lying and overlying sediments by erosional unconformities and contains numerous sea weed and mollusc remains as well as few pieces of gravel, but less shell debris. The gravel components are very well rounded (see Fig. 4). Well sorting and a unimodal grain size distribution is observed in subunit II with a well-defined peak at $>250 \mathrm{~mm}$ (LEF $1 / 3$, $47 / 2,47 / 3)$. In core LEF 47, subunit II is slightly fining upward.

On top of subunit II, again separated by an erosional unconformity, a massive third unit of gravel and sand was encountered in core LEF 1 (subunit III, LEF 1/2). The grain size analyses indicate a bimodal distribution. Due to the sedimentary and geochemical findings in lagoonal cores LEF 46 and 47, the coarse-grained unit is thinning towards the east as well (Figs. 4, 7). Here, subunit III was not encountered, and the basal homogeneous mud is only covered by a bipartite sandy sequence (subunits I and II).

In the prolongation of these cores, at vibracore site LEF 18 and trench LEF S1, no homogeneous mud sequence was found at the base (Fig. 4). The lowermost part of core LEF 18 consists of deeply weathered, well sorted silty fine sand. Towards the top of the unit, the content of silt and clay increases, and clear signs of hydromorphy as well as the 
brown colour point to soil formation at a former surface. Within the uppermost $20 \mathrm{~cm}$ of this unit, numerous ceramic fragments occur. The former surface is separated from the subsequent sediments by a distinct erosional unconformity. Above, a sand layer was found (0.37-0.08 m b.s.1.), including numerous mollusc remains and well-rounded pebbles. The grain size distribution is comparable to the pattern found for the samples of subunit I or subunit II from the Gyra fan (Fig. 5, LEF 18/3). Moreover, the sand contains specimens of the benthic foraminifera Peneroplis planatus, Elphidium crispum and Sorites orbicularis. Small intraclasts, consisting of sediment from the underlying unit, are incorporated and seem to represent rip-up clasts (Fig. 4). The uppermost part of the profiles is once again characterized by silty to clayey deposits. The massive sandy unit found at sites LEF 18 and LEF S1, on top of the deeply weathered former surface, is assumed to correlate with one of the subunits found in the sedimentary sequence of the Gyra fan.

Similar to transect A, the coarse-grained sequence is covered by greyish or brownish, homogeneous sediments at coring sites LEF 1, 46 and 47, mainly consisting of clay and silt.

\subsection{Results from the geochemical analyses}

In general, the geochemical findings reflect the results from the sedimentary investigations. The basal sandy unit in core LEF 1 is characterised by low LOI $(<5 \%)$ but high $\mathrm{CaCO}_{3}(>45 \%)$ values. The following unit of homogeneous mud shows higher LOI values $(>8 \%)$ in contrast. In particular the results from the XRF measurements reflect a distinct separation of the mud sediments - characterised by relatively low $\mathrm{Ca}(<15 \%)$ and $\mathrm{Sr}(<0.05 \%)$ but high $\mathrm{Fe}(>1.2 \%)$ values - from the following coarse-grained sequence, containing subunits I-IV (Figs. 3, 4). Here, entirely different geochemical characteristics are documented compared to the above and below lying silty and clayey sediments. High $\mathrm{Ca}(>30 \%)$ and $\mathrm{Sr}(>0.1 \%)$, an increased $\mathrm{Sr} / \mathrm{Fe}$ ratio as well as generally lower values of parameters indicating terrestrial influence, such as $\mathrm{Fe}(<0.5 \%)$ or $\mathrm{K}$, were detected. For the cores analysed by AAS (LEF 1 and 18), a similar pattern is illustrated by high $\mathrm{CaCO}_{3}(>45 \%)$ and low LOI $(<3 \%)$ values as well as increased $\mathrm{Na} / \mathrm{K}$ and $\mathrm{Ca} / \mathrm{K}$ ratios.

A more detailed look at the XRF measurements of cores LEF 44, 45, 47 and 50, however, reveals several further geochemical characteristics within the coarse-grained sequence. In particular for cores LEF 45, 47 and 50, a distinct decrease of the $\mathrm{Sr} / \mathrm{Fe}$ ratio is observed in the upper part of subunit I and (in the case of core LEF 50) subunit II, which were inferred from the sedimentary findings and where mud layers are present. Moreover, the $\mathrm{Sr} / \mathrm{Fe}$ ratio, though generally marked by higher values, is indicated by fluctuating distributions, not only at the boundary between but also within different subunits (particularly subunit II, LEF 44, 45; Fig. 3).

In the uppermost part of cores LEF 1 and $\mathrm{LEF} 44, \mathrm{CaCO}_{3}$ and $\mathrm{Na}$ values (LEF 1) as well as $\mathrm{Ca}$ and $\mathrm{Sr}$ contents (LEF 44) again decrease, while $\mathrm{K}$ and Fe contents as well as LOI values increase. A similar pattern was found for core LEF 18 , also situated a few $\mathrm{cm}$ a.s.l.

\subsection{Foraminiferal analyses of vibracore LEF 44}

For sediment profiles LEF 44 A and B (two overlapping parallel cores of LEF 44) detailed foraminiferal analyses and macrofaunal observations were carried out (Fig. 6). In total, 15 sediment samples were analyzed throughout the sedimentary sequence. In the fine-grained, silty to clayey unit at the base of the profile the benthic foraminiferal assemblage is composed of Ammonia spp., Haynesina germanica, Haynesina depressula, Quinqueloculina spp., Affinetrina planciana and Aubignyna perlucida; few isolated specimens of Peneroplis pertusus were detected. The lowermost sample shows slightly increased contents of fine sand. Here, several specimens of Peneroplis pertusus, Planorbulina mediterranensis and Cibicides lobatulus occur.

With the beginning of the subsequent coarse-grained sedimentary sequence, an overall increased diversity in the foraminiferal assemblage is apparent. This is particularly true for the bioclastic subunit at the base, characterized by abundant shell debris, and the lower part of the subsequent massive sandy subunit (Fig. 6, subunits I and II). Although the species found in the samples from the fine-grained unit below are still present, numerous additional benthic species appear. Here, Peneroplis pertusus and Peneroplis planatus are dominant; several other (in most cases epiphytic) species occur as well, such as Cibicidella variabilis, Elphidium macellum, Elphidium crispum, Miniacina miniacea, Neocorbina posidonicola, Sorites orbicularis and Cibicides lobatulus; the latter species was also found in a slightly sandy section intercalating the homogeneous mud. Some taxa like Gaudryna sp., Uvigerina mediterranea and Cibicides refulgens, as well as several planktonic tests, such as Globigerinoides sp., Neogloboquadrina sp. and Orbulina sp. were additionally found. Moreover, remains of sea urchins, fragments of bryozoa, a sponge spicule and several fibres of Posidonia sp. were encountered. In general, the tests of the encountered foraminifera are well preserved.

The upper part of the profile is characterized by the massive subunits II (sand and gravel) and III (mainly gravel, sandy matrix). Besides several taxa which were also found within the underlying units, these units are dominated by Elphidium crispum and Cibicides lobatulus. Remarkably, specimens in samples LEF 44A-3 and LEF 44B-1 are well preserved; above (LEF 44A-2) abundance and diversity as well as the state of preservation decrease. Most of the species documented for the fine-grained unit at the base of the profile show strongly reduced abundances. The marshy environment during deposition of the uppermost fine-grained sediments is indicated by the occurrence of Haplofragmoides jeffreysi in sample LEF 44A-1.

\subsection{Geochronological data}

For the geochronological interpretation of core LEF 1 and coring transect A, a sea weed remain (LEF 1/4+ PR, Table 1) was sampled from $1.21 \mathrm{~m}$ b.s.l. It was dated by ${ }^{14} \mathrm{C}$-AMS technique to 349-533 cal AD. From the base of the coarse-grained unit in sediment profile LEF S1, a bivalve test was dated to 475-258 cal BC (several age intervals; LEF S1/3 M, Table 1). Two ${ }^{14} \mathrm{C}$-AMS ages exist for vibracore transect $\mathrm{B}$. Plant remains taken from the lagoonal sediments below the coarse-grained sequence date to 509- 


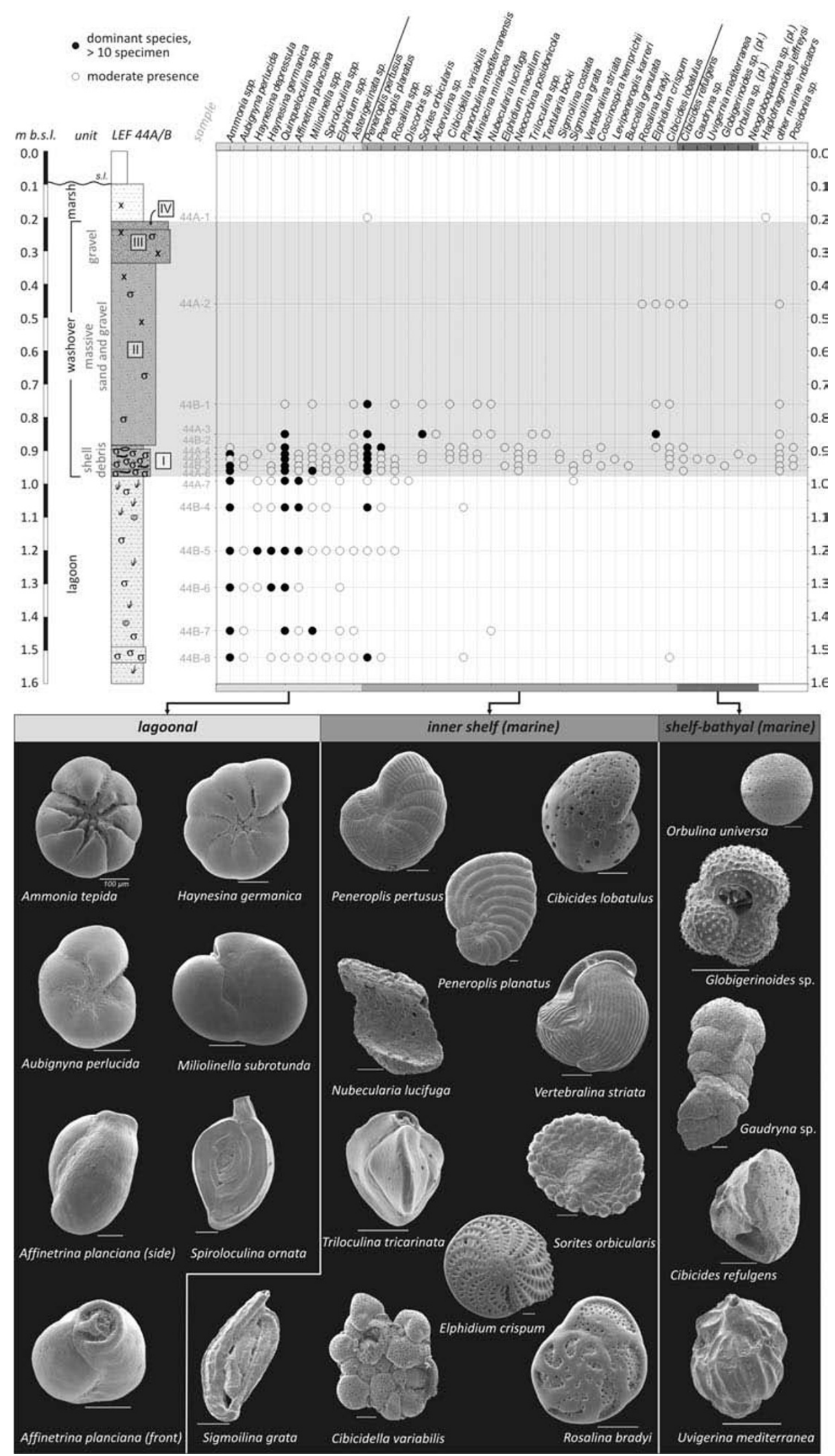

Fig. 6. Results of microfaunal analyses and SEM photographs of selected foraminifera of cores LEF 44A and LEF 44B. Stratigraphy slightly differs from core LEF 44. A distinct increase of diversity is documented from the lower part of the washover sequence. Here, a mixture of species from different foraminiferal assemblages is evident, including lagoonal species as well as abundant open marine species. Several planktonic species and species indicative of greater water depths were also found. For legend see Fig. 6. 
$395 \mathrm{cal}$ BC (several age intervals; LEF 44/10+ PR, $0.98 \mathrm{~m}$ b.s.l.) and 165-51 cal BC (LEF 45/9 PR, $0.64 \mathrm{~m}$ b.s.l.).

\section{Interpretation and Discussion}

\subsection{Palaeogeographical context}

The deepest core along the Gyra fan structure (LEF 1) shows well sorted fine to medium sand with a unimodal grain size distribution at its base. At the very base, these sediments are cemented to beachrock or a beackrock-like unit. According to their homogeneous appearance, their macrofaunal and sea weed content and their geochemical characteristics (low LOI and high $\mathrm{CaCO}_{3}$ values) these sediments are interpreted to represent sublittoral or littoral deposits. The subsequent thick sequence of grey mud is characterized by a relatively undisturbed, continuous sedimentation, a geochemical pattern indicating (semi-)terrestrial influence ( $\mathrm{Fe}$ values $>1.2 \%$ ) as well as an increased incorporation of organic material (high LOI values) during deposition. The foraminiferal assemblage is typical for lagoonal conditions, associated with a low-energy quiescent palaeoenvironment and the deposition of muddy sediments. Few specimens of Peneroplis pertusus possibly reflect minor influence of open marine waters (minor overwash events?) and the existence of the adjacent barrier beach system. In the lower part of the sequence the occurrence of Peneroplis pertusus, Planorbulina mediterranensis and Cibicides lobatulus may indicate increased marine influence, possibly due to minor washover-related sea water inundation. According to these findings, (i) a local retreat of the sea of at least $450 \mathrm{~m}$ and a related westward shift of the Gyrapetra barrier beach, (ii) an accompanied establishment of lagoonal conditions to the east of the shifting barrier beach, and (iii) a long period of relatively undisturbed lagoonal deposition is documented. In the eastern part of the Lefkada Lagoon, lagoonal conditions and the related Plaka barrier beach system were already established in the 6th millennium BC (Vött et al. 2007, 2009b). However, for the western part of the Lefkada Lagoon near the Gyra fan, no geochronological information on the onset of lagoonal conditions is available.

With the beginning of the following coarse-grained sediments (subunit I), a highly diverse foraminiferal assemblage, the occurrence of different, fully marine (allochthonous) and lagoonal (autochthonous, with respect to the location of the Gyra fan, stretching into the Lefkada Lagoon) foraminiferal assemblages, as well as an overall increased number of species is documented (Fig. 6). Several planktonic species (Globigerinoides sp., Neogloboquadrina sp. and Orbulina sp.) and species indicative of deeper water (Gaudryna sp., Uvigerina mediterranea and Cibicides refulgens) were detected, the latter typical for shelf-bathyal environments of greater water depths (Murray, 2006). Together with the sedimentary and geochemical characteristics showing, for instance, remarkably higher $\mathrm{Ca}$ and $\mathrm{Sr}$ as well as low Fe and LOI values (Figs. 3, 4; for comparable results see, e.g., Vött et al., 2002; Murray, 2006; Nichol et al., 2007) these findings give evidence of the open marine, sublittoral and/or littoral origin of the coarse-grained sedimentary sequence on top of the lagoonal mud. These results are concordant with results from geomorphological, sedi- mentological and micropalaeontologcial studies conducted in the eastern and central parts of the Lefkada Lagoon (Vött et al., 2009a).

In general, the deposition of open marine sediments on top of the lagoonal sequence may be explained (i) by a temporary re-establishment of littoral conditions due to sea level fluctuations, or (ii) by an event-induced transport of littoral and/or sublittoral material into the Lagoon of Lefkada, originating from the barrier beach, the foreshore area and the sea bottom off the Lefkada barrier. The local geomorphology does not show former beach ridges or comparable structures indicative of a shifting of the coastline but reveals a clear lobe-like fan structure. Moreover, the foraminiferal analyses clearly document the mixing of different, fully marine (allochthonous) and lagoonal (autochthonous) foraminiferal assemblages for the lowermost subunit I. The intermixture of allochthonous and autochthonous sediments is also deduced from the results of the grain size analyses, which indicate an exceptionally heterogeneous distribution and reflecting both marine and semi-terrestrial (and/or lagoonal) environments. These findings (i) point to an allochthonous formation of the deposit (Hawkes et al., 2007; Ruiz et al., 2010), and (ii) indicate erosion and subsequent incorporation of the underlying lagoonal sediments due to turbulent flow conditions. Together with the inferred local retreat of the sea due to gradual shoreline migration, documented by the sedimentary succession in the lower core section of core LEF 1 (lagoonal following the basal sublittoral sediments), the formation of the coarse-grained unit on top of the lagoonal mud thus cannot be explained by a temporary eastward shifting of the barrier beach and a related re-establishment of littoral conditions. It must rather be explained by an extensive washover event which inundated at least the western part of the Lefkada Lagoon. This confirms earlier investigations by Vött et al. (2006, 2009a).

\subsection{The formation of the Gyra fan}

5.2.1 Extension of the Gyra fan In principal, the Gyra fan might have formed due to tsunamis or extreme storm events. For the study area, the occurrence of tropicallike cyclones is unlikely, although their existence cannot be excluded (e.g. Emanuel, 2005). However, only exceptionally strong (winter or tropical-like) storms may theoretically have the energy to generate washover or breaching events along the Lefkada barrier beach system (Woodroffe, 2003: 461). As mentioned in Section 2.1, no major modifications of the back-barrier geomorphology are assumed at least during the last 150 years; thus, neither normal storm activity of annual, decadal (such as the storm described by Ghionis et $a l ., 2008$ ) or even centennial intensity nor younger tsunami events reported by tsunami catalogues for the years 1867 , $1869,1914,1915$ and 1948 significantly altered the backbarrier geomorphology in the study area.

The subaerial part of the Gyra washover structure comprises $\sim 390,000 \mathrm{~m}^{3}$ and extends for more than $1 \mathrm{~km}$ from the recent barrier beach into the Lefkada Lagoon. In many studies, the spatial dimensions of a washover structure are used as diagnostic criteria for the differentiation between tsunami and storm (Tuttle et al., 2004; Morton et al., 2007; Sugawara et al., 2008) and tsunami washover deposition 
is reported to exhibit larger dimensions than storm-induced washover deposition (Morton et al., 2007). With regard to the wave and storm climate of the eastern Mediterranean, the size of the Gyra fan thus provides indication for a tsunami-generated formation. However, storm-generated inundation by (outer-Mediterranean!) tropical cyclones is documented to have comparable dimensions (Fritz et al., 2009).

5.2.2 Inundation characteristics and sediment sources inferred from the foraminiferal analyses The presence of open marine species such as planktonic and/or outer shelf foraminifers indicates washover events and therefore storm and/or tsunami inundation if found in sediments intercalating the sedimentary sequence in backbarrier positions, such as lagoons or paralic swamps (e.g. Dawson et al., 1995; Mamo et al., 2009; Williams, 2009). Moreover, the mixing of different microfaunal assemblages (as found for subunit I) provides clear evidence for their event-induced origin. Due to the fact that the macro- and microfaunal content of an event deposit is a product of its source (Switzer and Jones, 2008a), these findings only prove the marine, washover-induced origin of the Gyra fan deposit. Taking the regional geomorphological contexts into account, numerous previous studies consider comparable findings to be characteristic for tsunami deposits (Hawkes et al., 2007; Kortekaas and Dawson, 2007; Mamo et al., 2009; Vött et al. 2009a). Similar macro- and microfaunal fingerprints were used to support the tsunamigenic origin of sediments in many cases (Hindson and Andrade, 1999; Nanayama and Shigeno, 2006; Dawson and Stewart, 2007). According to Uchida et al. (2010) the presence of species indicative of deeper water-such as Gaudryna sp., Uvigerina mediterranea and Cibicides refulgens presented in this study - may point to a tsunamigenic origin since these species represent indicators for a greater source depth and/or transport distance of the sediments.

In contrast to subunit I, the following thick subunit II is characterized by a dominance of the species Elphidium crispum and Cibicides lobatulus and the occurrence of several inner shelf taxa also documented for the underlying units, but brackish-lagoonal species recede. Additionally, the silt and clay fraction is almost absent in the related samples. Thus, the samples show typical characteristics of a sublittoral and/or littoral foraminiferal assemblage (e.g. Barbano et al., 2009; Mamo et al., 2009), and no lagoonal sediments from the underlying unit were reworked during the deposition of this subunit. Moreover, a different provenance area of the sediments comprising subunit II may be inferred. In this respect, investigations on the distribution pattern of different foraminiferal species in recent offshore sedimentary environments are required in search of potential provenance areas in the former pre-event littoral to inner-shelf zones and for the interpretation of event-related hydraulic processes.

5.2.3 Implications on sediment sources and inundation characteristics from the sedimentary findings Evidence for a tsunamigenic origin of the washover event may be derived from the presence of mud layers found in core LEF 50, 1-3 cm thick, and in core LEF 44, situated directly at the top of bioclastic subunit I, which are interpreted as mud drapes (Figs. 3, 5). In the latter case (LEF 44) the mud layer may also represent a rip-up clast. Moreover, the rip-up clasts at vibracore site LEF 18 indicate erosion of the former terrestrial surface below and high-energy turbulent flow during deposition. In general, mud layers or mud drapes are interpreted to form due to suspension fallout during slack water conditions after the decrease of flow velocities subsequent to a major inundation impulse during a tsunami event, where long wave periods ( $>10 \mathrm{~min}$.) explain intervals of stagnant flow velocity allowing for the accumulation of mud deposits (e.g., Fujiwara and Kamataki, 2007). Since intraclasts from the eroded underlying sediments and in particular internal mud drapes are reported to be a physical attribute found in numerous tsunami and only few storm deposits (e.g. Morton et al., 2007; Kortekaas and Dawson, 2007; Spiske, 2009; Williams, 2009), at least one tsunami event is considered to be responsible for the formation of the Gyra washover fan.

According to numerous findings worldwide, storminduced washover systems are characterized by a number of thin layers, lamina sets (typically 10 and more) and/or laminae, delta foreset stratification and subhorizontal, planar stratification with channel structures (Leatherman and Williams, 1977; Sedgwick and Davis, 2003; Morton et al., 2007; Williams, 2009). Lamination within tsunami deposits was described, for instance, by Paris et al. (2007), Choowong et al. (2008) and Morton et al. (2008) from sediments deposited by the 2004 Indian Ocean tsunami. The Lefkada Lagoon is connected to the Lefkada Sound leading southwards into the Bay of Drepano (Fig. 1; see also Vött et al., 2009a). Due to this topographical setting, inundating waters may not or much less be forced to return, and intense backwash-induced currents are assumed to be of minor importance for the investigated locations (see also Vött et al., 2009a). For subunit II in core LEF 44, sections of higher and lower gravel content are documented, but no clear internal sub-layering could be inferred. However, these findings may point to internal sub-stratification of subunit II for which the influence of backwash-induced currents cannot be excluded.

However, fewer sediment layers (typically not more than 3-5; subunits I, II, III and, for core LEF 44, IV in this study) are documented to comprise several tsunami deposits (e.g. Bahlburg and Weiss, 2007; Hawkes et al., 2007; Sugawara et al., 2008), and are not known to be produced by storm events. A tsunami-induced washover event, in contrast to a storm-induced event, would typically consist of few major impulses of sea water inundation, corresponding to the tsunami wave train. The characteristics of each flooding impulse considerably relate to several circumstances, such as near coastal bathymetry, slope of the coastal plain and shoreline morphology (e.g., Morton et al., 2007).

The distinct differentiation of four (I, II, III and IV; LEF 44), three (I, II and III; LEF 1, 45, 50) and/or two subunits (I and II; LEF 46, 47), separated by erosional unconformities in most cases, can be followed consistently along the entire investigated part of the fan structure (Figs. 3, $4,7)$. Altogether, the coarse sequence is thinning landward (south- and eastward, Fig. 7). The thickness of the presented subunits varies between the coring sites. Mas- 


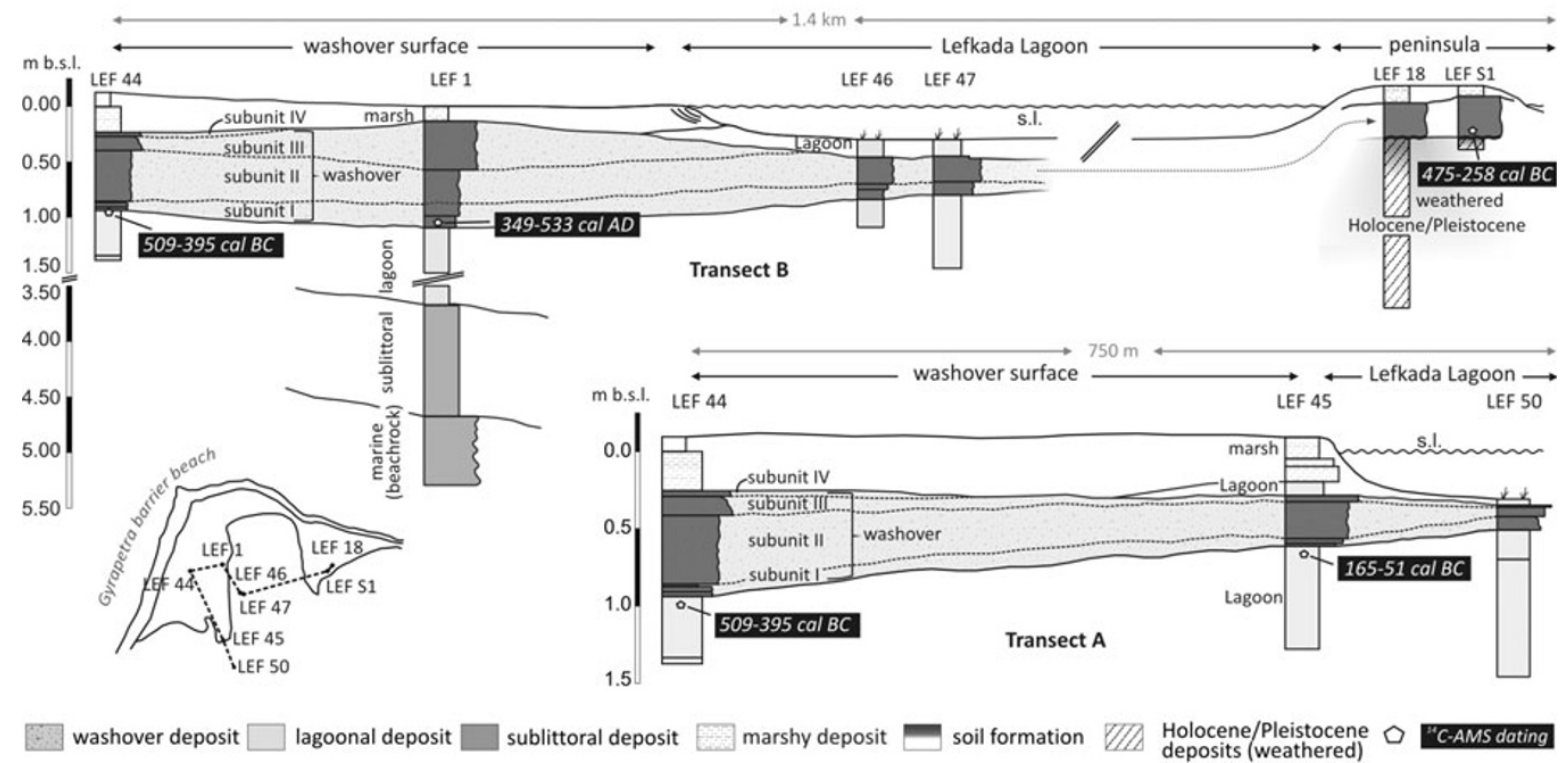

Fig. 7. Coring transects A and B carried out for the Gyra washover fan. Three distinct subunits within the washover deposit can be separated in cores LEF 1, LEF 45 and LEF 50. In core LEF 44 four subunits were detected; in cores LEF 46 and LEF 47, only two subunits were identified. The washover sequence shows fining and thinning landward features.

sive bedding (subunit IV, LEF 44), massive bedding with a fining-upward trend (subunit III, LEF 44), thick heterogeneous layers with possible sub-stratifications showing an overall fining-upward trend (subunit II, LEF 44, 45), clear fining-upward sequences (subunit I, LEF 50), remarkably heterogeneous (subunit I, LEF 44, 45, 47), unimodal (subunit II, LEF 1 and 47) as well as bimodal grain size distributions (subunits II and III, LEF 44) were encountered. Besides inferring differences in flow dynamics and involved transportation processes as well as decreasing transportation energy (fining-up sequences, mud drapes) during deposition of these subunits, the bimodality (fine to medium sand and very coarse sand to medium gravel) found for several samples point to multiple sediment sources-such as sublittoral (sand) and littoral (gravel) environments - within single and between different subunits. These findings are reported to be characteristic of several tsunami-induced deposits (e.g. Moore et al., 2006; Fujino et al., 2008; Switzer and Jones, 2008a). Moreover, observations during the 2004 Indian Ocean Tsunami (Morton et al., 2007) but also previous studies from Japan (e.g. Sato et al., 1995) showed that most of the sediments comprising these tsunami deposits originate from the littoral and the adjacent sublittoral zone. By investigating tsunami deposits from the 17 July, 1998 Papua New Guinea Tsunami and the 2004 Indian Ocean Tsunami, Gelfenbaum and Jaffe (2003) and Paris et al. $(2009,2010)$ concluded that these deposits mainly derived from offshore sediment sources; however, no indication for major sediment transport from furthest offshore areas was found (Paris et al., 2010), limiting the source of the deposits to shallower parts of the inner shelf.

For numerous cores, the grain size characteristics found within the washover unit are therefore in contrast to the grain size distribution found for the basal sandy unit in core LEF 1, which is characterized by well sorting and unimodality and which is interpreted as being of sublittoral ori- gin (Fig. 5). However, this is not the case for subunit II of cores LEF 1 and 47; here, the grain size pattern shows, similar compared to the results from the basal unit of LEF 1, a unimodal distribution, although it is interpreted to be part of the washover sequence (Fig. 5). It may thus be assumed that flow characteristics and sediment transport during inundation related to subunit II was different at the coring sites of transect A (eastward) when compared to transect B, where subunit II is characterized by a bimodal pattern and multiple sediment sources (sublittoral and littoral) are assumed. At coring sites LEF 1 and LEF 47 (transect B), only sediments of a single source, most likely sands of sublittoral origin, were accumulated.

Moreover, the first tsunami inundation pulse is commonly characterized by minor energy and related to limited inundation depth and distance (e.g. Choowong et al., 2008). The lower bioclastic subunit in the Gyra fan may be explained by the first flooding impulse of a tsunami event; here, the shell debris content may point to the separation or selection of distinct grain size fractions of bottom sediments by strong currents. Erosion, reworking and mixing of the underlying lagoonal mud and minor sediment load of the inundating waters took place. A waning phase and related suspension fallout during slack water conditions following the first inundation impulse is documented by the mud drape found in cores LEF 44 and 50 . It can be assumed that the second and subsequent flooding impulses were characterized by increased turbulence and suspension and/or sediment load in the water column compared to the first inundation impulse, triggering thicker event deposits in the geological record. Comparable observations were made by Choowong et al. (2008) and Fujiwara and Kamataki (2007). In the Gyra washover region the sand and gravel layers (sediments of subunit II) and the following gravel layers (sediments of subunit III) most likely correspond to inundation periods related to waves from the middle of the 
tsunami wave train (such as waves 2, 3 or 4 during a tsunami event, representing the strongest impulses) and, according to the partly bimodal grain size distribution, are characterized by a sublittoral to littoral provenance. If so, sediments from the waning stage of the tsunami, generally indicated by waves of minor energy and inundation distances, may only be represented by the thin fine gravel layer (subunit IV) in core LEF 44; for the other cores, analogous sediment layers of a distinct subunit IV have not been detected. However, open questions concerning (i) the contribution of distinct waves of the tsunami wave train to the sedimentary succession of the Gyra fan, and (ii) the correlation of the presented subunits to distinct waves of the tsunami wave train still remain.

5.2.4 Further implications from the geochemical results In general, the geochemical analyses support the interpretation based on the sedimentary findings. In the coarse-grained sequence (subunits I-IV), marine influence is clearly documented by increased $\mathrm{Sr}(>0.1 \%)$ and $\mathrm{Ca}$ (>30\%), by decreased Fe, and, for core LEF 1, by increased $\mathrm{Na}$ and decreased LOI $(<3 \%)$ values (cf., e.g., Chagué-Goff, 2010; Vött et al., 2002, 2011). Especially the low $\mathrm{Fe}$ values $(<0.5 \%)$ in subunits II and III indicate reduced terrigenous input during deposition of these sediments. However, increased input of terrigenous material is reported from several other tsunami deposits (e.g., Nanayama et al., 2000; Bony et al., 2011), where backwash currents transport terrestrial material (such as soil sediments, plant remains) seaward and the stratigraphy of the tsunami deposit contains distinct layers of backwash sediments. As described before, it is assumed that backwash is of minor importance for the investigated sites due to the topographical setting of the Lefkada Lagoon and the Lefkada Sound. However, the low values of the $\mathrm{Sr} / \mathrm{Fe}$ ratio in particular at the transition of subunit I to subunit II (e.g., LEF 45, $47,50)$ may indeed point to increased input of terrigenous material in the upper part of subunit I; here mud drapes were identified and interpreted to be related to suspension fallout during slack water conditions following the first inundation impulse. Since these finer sediments are associated to increasing Fe contents, a contribution of terrestrial material, such as soil sediments washed out from the adjacent coastal plain, seems plausible. However, the higher Fe contents may also be explained by suspension fallout of reworked sediments from the underlying mud.

Fluctuations of the $\mathrm{Sr} / \mathrm{Fe}$ ratio within different subunits were particularly detected in subunit II of cores LEF 44 and 45 (Fig. 3). According to the sedimentary findings, no distinct internal sub-layering of subunit II (and the other subunits) was found, but sections of higher and lower gravel content are documented. Here, these findings, together with the fluctuating geochemical pattern, may point to internal sub-layering or sub-stratification of subunit II, which may be explained by current-induced stratification. Further, more detailed investigations such as the study of trenches are needed to verify this hypothesis; they could not be carried out due to the high ground water table in the Gyra fan.

Finally, the original geochemical pattern of the washover deposit seems to be modified in the upper part of cores LEF 1, LEF 44 and LEF 18. These cores originate from locations with prevailing subaerial conditions where postdepositional subaerial weathering took place. Here, decalcification and soil formation processes (such as the in-situ production of $\mathrm{Fe}$ ) altered the geochemical fingerprint of the original deposit (cf. Szczuciński, 2012).

In summary, our results suggest a successive formation of four, three or two distinct subunits (I-IV) of the coarsegrained washover deposit during one single extreme wave event. However, it cannot be excluded that several independent washover events contributed to the formation of the coarse-grained sequence of the Gyra fan, since previous studies in the environs of the Sound of Lefkada report on multiple tsunami impact since the mid-Holocene (Vött et al., 2008, 2009a, b, 2010). The consistent morphology and stratigraphic architecture of the Gyra fan structure and the stratigraphic correlations, however, favour a quasicontemporaneous formation. No signs of intermittent soil formation, periods of subaerial weathering or periods of reestablished lagoonal deposition were found on top of any one of the subunits. Therefore, a successive deposition of the up to four subunits during one washover event is most likely, each subunit corresponding to one inundation impulse during this event.

\subsection{Geochronological implications and previous find- ings}

As for the geochronological interpretation of the washover event, two plant remains were taken from the underlying lagoonal unit (LEF 44/10+ PR and LEF 45/9 PR). Since a stratigraphical relation and a contemporaneous formation of the washover sediment is assumed, the younger age of 165-51 cal BC determines a maximum age for the deposition of the overlying washover sediments. Moreover, two ${ }^{14} \mathrm{C}$-AMS dates are available for vibracore transect A (LEF 1/4+ PR: 349-533 cal AD, LEF S1/3 M: 475-258 cal BC). Sample LEF 1/4+ PR was taken from subunit I and represents the most reliable estimation of the washover event. We thus assume that a major washover event, triggered by a tsunami, occurred around or after 349-533 cal $\mathrm{AD}$ in the western part of the study area (see also Vött et al., 2006).

In addition, the presented findings match investigations of Vött et al. (2008, 2009a) and May (2010) who presented sedimentary and microfaunal evidence for an event-induced formation of the Teki fan in the eastern part of the Lefkada Lagoon (see Fig. 1) and interpret the encountered depositional sequence as tsunamite. May (2010) concluded that the Teki fan could have formed around or after 157-399 cal $\mathrm{AD}$ and thus suggested that the formation of the fan took place later than previously inferred (Vött et al., 2009a); in that case, both washover structures, the Gyra and the Teki fan, may be related to the same event.

For the eastern Mediterranean, historical reports document a catastrophic tsunami following the 365 cal AD earthquake off western Crete (Pirazzoli, 1986; Kelletat, 1998; Stiros, 2001; Stefanakis, 2006). According to the modelled tsunami propagation presented by Shaw et al. (2008), sea surface heights off the Lekada-Preveza coast of $>0.5 \mathrm{~m}$ - similar to other coastal areas around the eastern Mediterranean-are inferred c. 60-70 min. after the earthquake. Since comparable open ocean amplitudes were cal- 
culated for the 2004 India Ocean Tsunami (e.g., Titov et al., 2005), remarkable wave amplification and thus strong onshore effects are assumed for the study area during the $365 \mathrm{AD}$ event.

Vött et al. (2009b) describe tsunami-related sediments from the south-western shore of the Lake Voulkaria, located some $12.5 \mathrm{~km}$ to the east of the Gyra fan behind a 5-18 m-high limestone sill. The related tsunami was dated to the end of the 4th century AD and thus was most probably initiated by the $365 \mathrm{AD}$ earthquake off western Crete (see also Vött and May, 2009). Moreover, event deposits related to the same tsunami of $365 \mathrm{AD}$ were recently found in geological archives in south-eastern Sicily (De Martini et al., 2010; Gerardi et al., 2010) and off the Sicilian coast (Smedile et al., 2011). Although local tectonics such as the Cefalonia transform fault cannot entirely be excluded as a triggering source, the results presented in this paper suggest that the formation of the Gyra fan may correspond to the well-known eastern Mediterranean catastrophe at 365 AD as well; according to the interpretation of May (2010), the Teki fan could have been triggered by the same event. The smaller Canali Stretti fan structure indicates at least one younger extreme wave event which must have taken place between the beginning of the 15th and the middle of the 19th century (May et al., 2012) and which altered the geomorphology in the Lefkada coastal zone.

\section{Conclusions}

In the study area, fan structures extending from the barrier beach into the shallow-water backbeach lagoonal area represent a prominent feature of the local coastal geomorphology. As documented for the Gyra fan, they consist of allochthonous, sublittoral and/or littoral sediments. Sedimentary and microfaunal characteristics match typical signatures reported from extreme wave deposits worldwide and provide clear evidence for its event-induced origin. However, most of these characteristics do not represent diagnostic, unambiguous criteria for the determination of the event source. The Gyra fan is built up of up to four stratigraphic subunits, each showing different sedimentary characteristics. This diagnostic feature together with the sheer dimension of the fan, its consistent general internal stratigraphical architecture, the occurrence of mud drapes between individual subunits and the synopsis of the sedimentary and microfaunal findings argue for a tsunami-induced rather than a storm-induced formation. This scenario fits best with the local geomorphological settings and the regional storm and wave climates. The subunits likely correspond to at least four major inundation phases during one tsunami event. Sediment transport and related deposition seem to have been largest during flooding impulses in the middle part of the tsunami wave train.

In general, we showed that palaeoevent research requires a holistic approach, combining comprehensive geomorphological, sedimentological and microfaunal analyses. The plausible and conclusive determination of the event source needs careful data interpretation and a collectivity of as many different criteria as possible. Thereby, the stratigraphical architecture of a candidate deposit is of major importance.
The formation of the Gyra washover fan took place around or after 349-533 cal AD. This age is consistent with and thus corroborates previous studies carried out in the Lefkada-Preveza area. The 365 cal AD earthquake off western Crete is considered as the most likely triggering source since, according to historical sources, the related tsunami affected large parts of the eastern Mediterranean.

According to the presented results, extreme wave impact considerably altered the geomorphological pattern of the study area.

Acknowledgments. We appreciate the assistance of K. Ntageretzis and S. Brockmüller during the work in the field and in the lab. Raphaël Paris and Osamu Fujiwara provided numerous helpful remarks during the review process. XRF measurements were carried out by H. Hadler. L. Kolonas (Athens), M. Stravropoulou (Ephoria of Akarnania, Mesolongion), and C. Melisch (Berlin) is thanked for administrative and logistic support in Greece. Work permits were issued by the Greek Institute of Geology and Mineral Exploration (IGME). We gratefully acknowledge the Deutsche Forschungsgemeinschaft (German Research Foundation) for funding (VO 938/2-1).

\section{References}

Ad-hoc-Arbeitsgruppe Boden der Staatlichen Geologischen Dienste und der Bundesanstalt für Geowissenschaften und Rohstoffe (editors), Bodenkundliche Kartieranleitung, 438 pp., Stuttgart, 2005 (in German).

AGIP (editors), Plate I-LII, in Foraminiferi Padani (Terziario e Quaternario), Milano, 1982.

Andrade, C., Tsunami generated forms in the Algarve Barrier Islands (South Portugal), Sci. Tsunami Haz., 10, 21-34, 1992.

Andrade, C., M. C. Freitas, J. Moreno, and S. C. Craveiro, Stratigraphical evidence of Late Holocene barrier breaching and extreme storms in lagoonal sediments of Ria Formosa, Algarve, Portugal, Mar. Geol., 210, 339-362, 2004.

Bahlburg, H. and R. Weiss, Sedimentology of the December 26, 2004, Sumatra tsunami deposits in eastern India (Tamil Nadu) and Kenya, Int. J. Earth Sci., 96, 1195-1209, 2007.

Barbano, M. S., P. M. De Martini, D. Pantosti, A. Smedile, P. Del Carlo, F. Gerardi, P. Guarnieri, and C. Pirrotta, In search of tsunami deposits along the eastern coast of Sicily (Italy): State of the art, in Recent Progress on Earthquake Geology, edited by P. Guarnieri, 257 pp., Nova Science Pub., Hauppauge, ISBN: 978-1-60876-147-0, 2009.

Barbano, M. S., C. Pirrotta, and F. Gerardi, Large boulders along the southeastern Ionian coast of Sicily: Storm or tsunami deposits?, Mar. Geol., 275, 140-154, 2010.

Beck, R., D. Burger, and K.-H. Pfeffer, Laborskript. Kleinere Arbeiten aus dem Geographischen Institut der Universität Tübingen, 11, 1995 (in German).

Benner, R., T. Browne, H. Brückner, D. Kelletat, and A. Scheffers, Boulder transport by waves: Progress in physical modelling, Zeitschrift für Geomorphologie, 54, Suppl. 3, 127-146, 2010.

Blott, S. J. and K. Pye, Gradistat, A grain size distribution and statistics package for the analysis of unconsolidated sediments, Earth Surf. Process. Landforms, 26, 1237-1248, 2001.

Bony, G., N. Marriner, C. Morhange, D. Kaniewski, and D. Perinçek, A high-energy deposit in the Byzantine harbour of YenikapI, Istanbul (Turkey), Quatern. Int., doi:10.1016/j.quaint.2011.03.031, 2011.

Chagué-Goff, C., Chemical signatures of palaeotsunamis: A forgotten proxy?, Mar. Geol., 271, 67-71, 2010.

Choowong, M., N. Murakoshi, K.-I. Hisada, P. Charusiri, T. Charoentitirat, V. Chutakositkanon, K. Jankaew, P. Kanjanapayont, and S. Phantuwongraj, 2004 Indian Ocean tsunami inflow and outflow at Phuket, Thailand, Mar. Geol., 248, 179-192, 2008.

Cimerman, F. and M. R. Langer, Mediterranean Foraminifera, Academia Scientiarum et Artium Slovenica Classis IV, 30, 1991.

Dawson, A. G., The geological significance of tsunamis, Zeitschrift für Geomorphologie N.F. Suppl. Vol., 102, 199-210, 1996.

Dawson, A. G. and I. Stewart, Tsunami deposits in the geological record, Sediment. Geol., 200, 166-183, 2007.

Dawson, A. G., R. Hindson, C. Andrade, C. Freitas, R. Parish, and M. Bateman, Tsunami sedimentation associated with the Lisbon earth- 
quake of 1 November AD 1755: Boca do Rio, Algarve, Portugal, The Holocene, 5, 209-215, 1995.

De Martini, P. M., M. S. Barbano, A. Smedile, F. Gerardi, D. Pantosti, P. Del Carlo, and C. Pirrotta, A unique 4000 year long geological record of multiple tsunami inundations in the Augusta Bay (eastern Sicily, Italy), Mar. Geol., 276, 42-57, 2010.

Donnelly, J. P., J. Butler, S. Roll, M. Wengren, and T. Webb, A backbarrier overwash record of intense storms from Brigantine, New Jersey, Mar. Geol., 210, 107-121, 2004.

Doutsos, T. and S. Kokkalas, Stress and deformation patterns in the Aegean region, J. Struct. Geol., 23, 455-472, 2001

Emanuel, K., Genesis and maintenance of "Mediterranean hurricanes", Adv. Geosci., 2, 217-220, 2005.

Engel, M., H. Brückner, V. Wennrich, A. Scheffers, D. Kelletat, A. Vött, F. Schäbitz, G. Daut, T. Willershäuser, and S. M. May, The back-barrier record of eastern Bonaire (Netherlands Antilles): New insights into the palaeo-tsunami history of the southern Caribbean, Sediment. Geol., 231, 14-30, 2010

Fritz, H. M., C. D. Blount, S. Thwin, M. K. Thu, and N. Chan, Cyclone Nargis storm surge in Myanmar, Nature Geosci., 2, 448-449, 2009.

Fujino, S., H. Naruse, A. Suphawajruksakul, T. Jarupongsakul, M. Murayama, and T. Ichihara, Thickness and grain-size distribution of Indian Ocean tsunami deposits at Khao Lak and Phra Thong Island, Southwestern Thailand, in Tsunamiites, edited by T. Shiki, Y. Tsuji, T. Yamazaki, and K. Minoura, 432 pp., Elsevier, Amsterdam, 2008.

Fujiwara, O. and T. Kamataki, Identification of tsunami deposits considering the tsunami waveform: An example of subaqueous tsunami deposits in Holocene shallow bay on southern Boso Peninsula, Central Japan, Sediment. Geol., 200, 295-313, 2007.

Gelfenbaum, G. and B. Jaffe, Erosion and Sedimentation from the 17 July, 1998 Papua New Guinea Tsunami, Pure Appl. Geophys., 160, 19691999, 2003.

Gerardi, F., M. S. Barbano, C. Pirrotta, P. M. De Martini, A. Smedile, S Pinzi, and P. Del Carlo, Geological evidence of tsunami inundation in south-eastern Sicily: A record of the 365 A.D. Crete earthquake?, 3rd International Tsunami Field Symposium, Sendai, Japan, Abstract Book, 49-50, 2010.

Ghionis, G., S. Poulos, N. Kampanis, E. Verikiou, A. Karditsa, G. Alexandrakis, and P. Andris, The effects of a severe storm event on the NW coast of Lefkada Island, Ionian Sea (Greece), Geophys. Res. Abstr., 10, EGU2008-A-00617, 2008

Goff, J., B. G. Mcfadgen, and C. Chagué-Goff, Sedimentary differences between the 2002 Easter storm and the 15th-century Okoropunga tsunami, southeastern North Island, New Zealand, Mar. Geol., 204, 235-250, 2004

Goff, J. R., E. Lane, and J. Arnold, The tsunami geomorphology of coastal dunes, Nat. Haz. Earth Syst. Sci., 9, 847-854, 2009.

Haslinger, F., E. Kissling, J. Ansorge, D. Hatzfeld, E. Papadimitriou, V. Karakostas, K. Makropoulos, H.-G. Kahle, and Y. Peter, 3D crustal structure from local earthquake tomography around the Gulf of Arta (Ionian region, NW Greece), Tectonophysics, 304, 201-218, 1999.

Hawkes, A. D., M. Bird, S. Cowie, C. Grundy-Warr, B. P. Horton, A. T. S. Hwai, L. Law, C. Macgregor, J. Nott, J. E. Ong, J. Rigg, R. Robinson, M. Tan-Mullins, T.-T. Sa, Z. Yasin, and L. W. Aik, Sediments deposited by the 2004 Indian Ocean Tsunami along the Malaysia-Thailand Peninsula, Mar. Geol., 242, 169-190, 2007.

Hindson, R. A. and C. Andrade, Sedimentation and hydrodynamic processes associated with the tsunami generated by the 1755 Lisbon earthquake, Quatern. Int., 56, 27-38, 1999

Kelletat, D., Geologische Belege katastrophaler Erdkrustenbewegungen 365 AD im Raum von Kreta, Geographica Historica, 10, 156-161, 1998 (in German).

Kenna, T. C., F. O. Nitsche, M. M. Herron, B. J. Mailloux, D. Peteet, S. Sritrairat, E. Sands, and J. Baumgarten, Evaluation and calibration of a Field Portable X-Ray Fluorescence spectrometer for quantitative analysis of siliciclastic soils and sediments, J. Anal. At. Spectrom., 26, 395-405, 2010

Kortekaas, S. and A. G. Dawson, Distinguishing tsunami and storm deposits: An example from Martinhal, SW Portugal, Sediment. Geol., 200, 208-221, 2007.

Krestenitis, Y. N., Y. S. Androulidakis, Y. N. Kontos, and G. Georgakopoulos, Coastal inundation in the north-eastern Mediterranean coastal zone due to storm surge events, J. Coast. Conserv., 15, 353-368, 2011.

Leatherman, S. P. and A. T. Williams, Lateral textural grading in overwash sediments, Earth Surf. Process. Landforms, 2, 333-341, 1977.

Louvari, E., A. A. Kiratzi, and B. C. Papazachos, The Cephalonia Trans- form Fault and its extension to western Lefkada Island (Greece), Tectonophysics, 308, 223-236, 1999.

Luque, L., J. Lario, J. Civis, P. G. Silva, C. Zazo, J. L. Goy, and C. J. Dabrio, Sedimentary record of a tsunami during Roman times, Bay of Cadiz, Spain, J. Quatern. Sci., 17, 623-631, 2002.

Mamo, B., L. Strotz, and D. Dominey-Howes, Tsunami sediments and their foraminiferal assemblages, Earth-Sci. Rev., 96, 263-278, 2009.

Matias, A., Ó. Ferreira, A. Vila-Concejo, T. Garcia, and J. A. Dias, Classification of washover dynamics in barrier islands, Geomorphology, 97, 655-674, 2008

May, S. M., Sedimentological, geomorphological and geochronological studies on Holocene tsunamis in the Lefkada-Preveza area (NW Greece) and their implications for coastal evolution, $\mathrm{PhD}$ thesis, Universität zu Köln, 2010 (http://kups.ub.uni-koeln.de/volltexte/2010/3189/).

May, S. M., A. Vött, H. Brückner, R. Grapmayer, M. Handl, and V. Wennrich, The Lefkada barrier and beachrock system (NW Greece)controls on coastal evolution and the significance of extreme wave events, Geomorphology, 139-140, 330-347, 2012.

Moore, A., Y. Nishimura, G. Gelfenbaum, T. Kamataki, and R. Triyono, Sedimentary deposits of the 26 December 2004 tsunami on the northwest coast of Aceh, Indonesia, Earth Planets Space, 58, 253-258, 2006.

Morales, J. A., J. Borrego, E. G. San Miguel, N. López-González, and B. Carro, Sedimentary record of recent tsunamis in the Huelva Estuary (southwestern Spain), Quatern. Sci. Rev., 27, 734-746, 2008.

Morton, R. A., G. Gelfenbaum, and B. E. Jaffe, Physical criteria for distinguishing sandy tsunami and storm deposits using modern examples, Sediment. Geol., 200, 184-207, 2007.

Morton, R. A., J. R. Goff, and S. L. Nichol, Hydrodynamic implications of textural trends in sand deposits of the 2004 tsunami in Sri Lanka, Sediment. Geol., 207, 56-64, 2008.

Murray, J. W., Ecology and Applications of Benthic Foraminifers, 439 pp., Cambridge University Press, Cambridge, 2006.

Nanayama, F. and K. Shigeno, Inflow and outflow facies from the 1993 tsunami in southwest Hokkaido, Sediment. Geol., 187, 139-158, 2006.

Nanayama, F., K. Shigeno, K. Satake, K. Shimokawa, S. Koitabashi, S. Miyasaka, and M. Ishii, Sedimentary differences between the 1993 Hokkaido-nansei-oki tsunami and the 1959 Miyakojima typhoon at Taisei, southwestern Hokkaido, northern Japan, Sediment. Geol., 135, 255 $264,2000$.

NASA (National Aeronautics and Space Administration), SRTM elevation data, http://www2.jpl.nasa.gov/srtm/, 01/2006.

Nichol, S. L., J. R. Goff, R. J. N. Devoy, C. Chagué-Goff, B. Hayward, and I. James, Lagoon subsidence and tsunami on the West Coast of New Zealand, Sediment. Geol., 200, 248-262, 2007.

Papadopoulos, G. A., V. K. Karastathis, A. Ganas, S. Pavlides, A. Fokaefs, and K. Orfanogiannaki, The Lefkada, Ionian Sea (Greece), shock, (Mw 6.2) of 14 August 2003: Evidence for the characteristic earthquake from seismicity and ground failures, Earth Planets Space, 55, 713-718, 2003.

Papazachos, B. C. and P. P. Dimitriu, Tsunamis in and near Greece and their relation to the earthquake focal mechanisms, Nat. Haz., 4, 161170, 1991

Paris, R., F. Lavigne, P. Wassmer, and J. Sartohadi, Coastal sedimentation associated with the December 26, 2004 tsunami in Lhok Nga, west Banda Aceh (Sumatra, Indonesia), Mar. Geol., 238, 93-106, 2007.

Paris, R., P. Wassmer, J. Sartohadi, F. Lavigne, B. Barthomeuf, E. Desgages, D. Grancher, P. Baumert, F. Vautier, D. Brunstein, and C. Gomez, Tsunamis as geomorphic crises: Lessons from the December 26, 2004 tsunami in Lhok Nga, West Banda Aceh (Sumatra, Indonesia), Geomorphology, 104, 59-72, 2009.

Paris, R., J. Fournier, E. Poizot, S. Etienne, J. Morin, F. Lavigne, and P. Wassmer, Boulder and fine sediment transport and deposition by the 2004 tsunami in Lhok Nga (western Banda Aceh, Sumatra, Indonesia): A coupled offshore-onshore model, Mar. Geol., 268, 43-54, 2010.

Partsch, J., Das Alter der Inselnatur von Leukas, Petermanns Geographis che Mitteilungen, 53, 269-278, 1907 (in German).

Pirazzoli, P. A., The early Byzantine Tectonic Paroxysm, Zeitschrift für Geomorphologie, N.F., Suppl., 62, 31-49, 1986.

Radu, T. and D. Diamond, Comparison of soil pollution concentrations determined using AAS and portable XRF techniques, J. Haz. Mater. 171, 1168-1171, 2009.

Reimer, P. J. and F. G. McCormac, Marine radiocarbon reservoir corrections for the Mediterranean and Aegean Seas, Radiocarbon, 44, 159166,2002

Reimer, P. J., M. G. L. Baillie, E. Bard, A. Bayliss, J. W. Beck, P. G. Blackwell, C. Bronk Ramsey, C. E. Buck, G. S. Burr, R. L. Edwards, M. Friedrich, P. M. Grootes, T. P. Guilderson, I. Hajdas, T. J. Heaton, A. 
G. Hogg, K. A. Hughen, K. F. Kaiser, B. Kromer, F. G. McCormac, S. W. Manning, R. W. Reimer, D. A. Richards, J. R. Southon, S. Talamo, C. S. M. Turney, J. van der Plicht, and C. E. Weyhenmeyer, IntCal09 and Marine09 radiocarbon age calibration curves, 0-50,000 Years cal BP, Radiocarbon, 51, 1111-1150, 2009.

Ruiz, F., M. Abad, L. M. Cáceres, J. Rodríguez Vidal, M. I. Carretero, M. Pozo, and M.-L. González-Regalado, Ostracods as tsunami tracers in Holocene sequences, Quatern. Res., 73, 130-135, 2010.

Sachpazi, M., A. Hirn, C. Clément, F. Haslinger, M. Laigle, E. Kissling, P. Charvis, Y. Hello, J. C. Lépine, M. Sapin, and J. Ansorge, Western Hellenic subduction and Cephalonia Transform: local earthquakes and plate transport and strain, Tectonophysics, 319, 301-319, 2000.

Sato, H., T. Shimamoto, A. Tsutsumi, and E. Kawamoto, Onshore tsunami deposits caused by the 1993 Southwest Hokkaido and 1983 Japan Sea earthquakes, Pure Appl. Geophys., 144, 693-717, 1995.

Scicchitano, G., C. Monaco, and L. Tortorici, Large boulder deposits by tsunami waves along the Ionian coast of south-eastern Sicily (Italy), Mar. Geol., 238, 75-91, 2007.

Sedgwick, P. E. and R. A Davis, Stratigraphy of washover deposits in Florida: Implications for recognition in the stratigraphic record, Mar. Geol., 200, 31-48, 2003.

Sgarrella, F. and M. Moncharmont Zei, Benthic foraminifera of the Gulf of Naples (Italy): systematics and autoecology, Bollettino della Società Paleontologica Italiana, 32, 145-264, 1993.

Shaw, B., N. N. Ambraseys, P. C. England, M. A. Floyd, G. J. Gorman, T. F. G. Higham, J. A. Jackson, J.-M. Nocquet, C. C. Pain, and M. D. Piggott, Eastern Mediterranean tectonics and tsunami hazard inferred from the AD 365 earthquake, Nature Geosci., 1, 268-276, 2008.

Smedile, A., P. M. De Martini, D. Pantosti, L. Bellucci, P. Del Carlo, L. Gasperini, C. Pirrotta, A. Polonia, and E. Boschi, Possible tsunami signatures from an integrated study in the Augusta Bay offshore (Eastern Sicily-Italy), Mar. Geol., 281, 1-13, doi:10.1016/j.margeo.2011.01.002, 2011.

Spiske, M., Sedimentology and hydrodynamics of high-energy wave events, PhD thesis, Wilhelms-Universität Münster, 2009.

Stefanakis, M. I., Natural catastrophes in the Greek and Roman World: Loss or gain? Four cases of seaquake-generated tsunamis, Mediterranean Archaeology and Archaeometry, 6, 61-88, 2006.

Stiros, S. C., The AD 365 Crete earthquake and possible seismic clustering during the fourth to sixth centuries AD in the Eastern Mediterranean: A review of historical and archaeological data, J. Struct. Geol., 23, 545$562,2001$.

Sugawara, D., K. Minoura, and F. Imamura, Tsunamis and tsunami sedimentology, in Tsunamiites, edited by T. Shiki, Y. Tsuji, T. Yamazaki, and K. Minoura, 432 pp., Elsevier, Amsterdam, 2008.

Switzer, A. D. and B. G. Jones, Large-scale washover sedimentation in a freshwater lagoon from the southeast Australian coast: Sea-level change, tsunami or exceptionally large storm?, The Holocene, 18, 787803, 2008a.

Switzer, A. D. and B. G. Jones, Setup, deposition, and sedimentary characteristics of two storm overwash deposits, Abrahams Bosom Beach, Southeastern Australia, J. Coast. Res., 24, 189-200, 2008 b.

Szczuciński, W., The post-depositional changes of the onshore 2004 tsunami deposits on the Andaman Sea coast of Thailand, Nat. Haz., 60, 115-133, 2012.

Titov, V., A. B. Rabinovich, H. O. Mofjeld, R. E. Thomson, and F. I. Gonzalez, The Global Reach of the 26 December 2004 Sumatra Tsunami, Science, 309, 2045-2048, 2005.

Tuttle, M. P., A. Ruffman, T. Anderson, and H. Jeter, Distinguishing tsunami from storm deposits in Eastern North America: The 1929 Grand Banks tsunami versus the 1991 Halloween storm, Seismol.Res. Lett., 75,
117-131, 2004.

Uchida, J., O. Fujiwara, S. Hasegawa, and T. Kamataki, Sources and depositional processes of tsunami deposits: Analysis using foraminiferal tests and hydrodynamic verification, Island Arc, 19, 427-442, 2010.

USGS (United States Geological Survey), Earth Resources Observation and Science (EROS), Aster satellite data, http://edc.usgs.gov, 01/2006.

Vött, A., Relative sea level changes and regional tectonic evolution of seven coastal areas in NW Greece since the mid-Holocene, Quatern. Sci. Rev., 26, 894-919, 2007.

Vött, A. and S. M. May, Auf den Spuren von Tsunamis im östlichen Mittelmeer, Geographische Rundschau, 12, 42-48, 2009 (in German).

Vött, A., M. Handl, and H. Brückner, Rekonstruktion holozäner Umweltbedingungen in Akarnanien (Nordwestgriechenland) mittels Diskriminanzanalyse von geochemischen Daten, Geologica et Palaeontologica, 36, 123-147, 2002 (written in German).

Vött, A., M. May, H. Brückner, and S. Brockmüller, Sedimentary evidence of late Holocene tsunami events near Lefkada Island (NW Greece), Zeitschrift für Geomorphologie N.F. Suppl. Vol., 146, 139-172, 2006.

Vött, A., H. Brückner, M. May, F. Lang, and S. Brockmüller, Late Holocene tsunami imprint at the entrance of the Ambrakian Gulf (NW Greece), Mediterranée, 108, 43-57, 2007.

Vött, A., H. Brückner, M. May, F. Lang, R. Herd, and S. Brockmüller, Strong tsunami impact on the Bay of Aghios Nikolaos and its environs (NW Greece) during Classical-Hellenistic times, Quatern. Int., 181, 105-122, 2008.

Vött, A., H. Brückner, S. Brockmüller, M. Handl, S. M. May, K. GakiPapanastassiou, R. Herd, F. Lang, H. Maroukian, O. Nelle, and D. Papanastassiou, Traces of Holocene tsunamis across the Sound of Lefkada, NW Greece, Global Planet. Change, 66, 112-128, 2009a.

Vött, A., H. Brückner, S. M. May, D. Sakellariou, O. Nelle, F. Lang, V. Kapsimalis, S. Jahns, R. Herd, M. Handl, and I. Fountoulis, The Lake Voulkaria (Akarnania, NW Greece) palaeoenvironmental archive-a sediment trap for multiple tsunami impact since the mid-Holocene, Zeitschrift für Geomorphologie N.F. Suppl. Issue, 53, 1-37, $2009 \mathrm{~b}$.

Vött, A., G. Bareth, H. Brückner, C. Curdt, I. Fountoulis, R. Grapmayer, H. Hadler, D. Hoffmeister, N. Klasen, F. Lang, P. Masberg, S. M. May, K. Ntageretzis, D. Sakellariou, and T. Willershäuser, Beachrock-type calcarenitic tsunamites along the shores of the eastern Ionian Sea (western Greece) - case studies from Akarnania, the Ionian Islands and the western Peloponnese, Zeitschrift für Geomorphologie N.F. Suppl. Issue, 54, $1-50,2010$.

Vött, A., F. Lang, H. Brückner, K. Gaki-Papanastassiou, H. Maroukian, D. Papanastassiou, A. Giannikos, H. Hadler, M. Handl, K. Ntageretzis, T. Willershäuser, and A. Zander, Sedimentological and geoarchaeological evidence of multiple tsunamigenic imprint on the Bay of PalairosPogonia (Akarnania, NW Greece), Quatern. Int., 242, 213-239, 2011.

Walker, M. J. C., Quaternary Dating Methods, 286 pp., Wiley, Chichester, 2005.

Williams, H. F. L., Stratigraphy, sedimentology, and microfossil content of Hurricane Rita storm surge deposits in Southwest Louisiana, J. Coast. Res., 25, 1041-1051, 2009.

Woodroffe, C., Coasts-Form Processes and Evolution, 623 pp., Cambridge University Press, Cambridge, 2003.

Zhu, Y. and D. C. Weindorf, Determination of soil calcium using field portable X-ray fluorescence, Soil Sci., 174, 151-155, doi:10.1097/SS.0b013e31819c6e1b, 2009.

S. M. May (e-mail: mays@uni-koeln.de), A. Vött, H. Brückner, and A. Smedile 